\title{
Tinjauan Teologis Tentang Gereja Dan Pertumbuhannya Berdasarkan Kitab Kisah Para Rasul
}

\author{
Gunar Sahari \\ Sekolah Tinggi Teologi Pelita Dunia, Tangerang \\ gunar.sahari@gmail.com
}

\begin{abstract}
This study discusses the Theological Review of the Church and Its Growth Based on the Book of Acts. Researchers used qualitative methods to study this topic. After conducting the research, the researchers concluded that the Acts of the Apostles provided an excellent picture of church growth to serve as the biblical basis for studies of church growth today.
\end{abstract}

Keywords: Church, Church Growth, Acts of the Apostles

Abstrak: Penelitian ini membahas tentang Tinjauan Teologis Gereja dan Pertumbuhannya Berdasarkan Kitab Kisah Para Rasul. Peneliti menggunakan metode kualitatif untuk mengkaji topik ini. Setelah melakukan penelitian, maka peneliti memperoleh kesimpulan bahwa Kisah Para Rasul memberikan gambaran pertumbuhan gereja yang sangat baik untuk dijadikan dasar Alkitab untuk studi-studi pertumbuhan gereja masa kini.

Kata Kunci: Gereja, Pertumbuhan Gereja, Kisah Para Rasul

\section{Pendahuluan}

Dalam pendahuluan kitab Kisah Para Rasul penulis mengatakan "Hai Teofilus, dalam bukuku yang pertama aku menulis tentang segala sesuatu yang dikerjakan dan diajarkan Yesus, sampai pada hari Ia terangkat" (Kisah Para Rasul 1:1). Dari kalimat ini dapat dipahami bahwa kitab Kisah Para Rasul merupakan lanjutan dari kitab sebelumnya. Mengenai kitab Kisah Para Rasul sebagai kitab lanjut, J. Sidlow Baxter mengatakan; "Injili Lukas diakhiri dengan cerita kenaikkan Tuhan Yesus, dan kitab Kisah Para Rasul dimulai dengan kenaikkan itu. Jadi kitab Kisah Para Rasul adalah lanjutan kitab Injil Lukas."1 Sedangkan Tom Jacobs SJ. Mengatakan: "kitab Kisah Para Rasul bukanlah sebuah buku laporan biasa. Lukas penulis kisah ini adalah seorang beriman yang terlibat dalam hidup dan perkembangan gereja."2 Selanjutnya Ola Tulluan, Ph.D., seorang pakar pengantar Perjanjian Baru mengatakan: "Lukas itu memang cocok untuk menulis Kisah Para Rasul, karena dia mengenal secara pribadi orang yang disebut dengan nama “... Teofilus, ..."3

\footnotetext{
${ }^{1}$ J.Sidlow Baxter, Menggali Isi Alkitab Matius S/d Kisah Para Rasul, (Jakarta: Yayasan Komunitas Bina Kasih, 1991), hlm. 296.

${ }^{2}$ Tom Jacobs SJ, Gereja Menurut Perjanjian Baru, Yogyakarta: Kanasius, 1992, hlm. 81.

${ }^{3}$ Pdt. Ola Tulluan, Ph.D. Diktat Indtroduksi Perjanjian Baru, (Malang: Departemen Literatur YPPII, t.th), hlm. 59.
} 
Dari pernyataan-pernyataan diatas jelaslah bahwa kitab Kisah Para Rasul ditulis oleh orang yang terlibat langsung dalam peristiwa pertumbuhan gereja mula-mula, sehingga cukup mengenal situasi dan perkembangan yang ada dan dapat menulis dengan detail tentang pola pelayanan dan pertumbuhan gereja mula-mula, sebab penulis mengenal Bernabas dengan dekat (Kisah Para Rasul 13:1-2). Bahkan penulis mempunyai hubungan pribadi dengan Felipus (Kisah Para Rasul 21:8) kawan sekerjanya Stefanus (Kisah Para Rasul 6:5) dan rekan-rekan sekerja rasul Paulus yang lainnya.

Tentang hubungan penulis dengan rasul Paulus dan rekan-rekan sekerjanya, maka Ola Tulluan mengatakan: "Lukas sungguh menguasai bahan-bahan yang dilaporkan dalam Kisah Para Rasul."4 Dengan demikian dapat disimpulkan dan dipercaya bahwa kitab Kisah Para Rasul ditulis oleh tabib Lukas. Karena kitab Injil Lukas dan kitab Kisah Para Rasul adalah satu buku yang disusun dalam dua jilid.

Lukas penulis kitab Injil Lukas dan kitab Kisah Para Rasul adalah "pendamping setia dari seorang utusan Injil yang besar yaitu Paulus, iman agamawinya baginya persoalan hidup atau mati." ${ }^{5}$ Maksud pernyataan ini bahwa tabib Lukas adalah rekan yang setia mendampingi rasul Paulus dalam pelayanan (Filemon 1:24; II Timotius 4:11). Tabib Lukas adalah seorang Yunani dari Antiokhia. Dari gaya sastra dalam penulisannya, jelaslah bahwa Lukas seorang berpenddidikan tinggi yaitu seorang tabib atau dokter (Kolose 4:14). Dengan demikian dapat dipastikan bahwa Lukas adalah tabib/dokter pribadi dari rasul Paulus selama masa tahanannya yang ke dua di Roma, sesaat sebelum kematiannya sebagai martir.

Kitab Kisah Para Rasul dialamatkan secara khusus kepada Teofilus yang mulia (Kisah Para Rasul 1:1). "Seluruh karya dikerjakan agar seorang Teofilus dapat memperoleh laporan yang teratur dan dapat dipercaya mengenai timbulnya dan berkembangnya agama Kristen - walaupun ia sudah memiliki beberapa informasi mengenai hal itu."6 Maksudnya bahwa kitab Kisah Para Rasul merupakan laporan perkembangan agama Kristen dari tabib Lukas kepada Teofilus seorang yang berlatar belakang agama kafir, namun setia mengikuti perkembangan agama Kristen lewat pelayanan Rasul Paulus. Selanjutnya Ola Tulluan, Ph.D. mengatakan bahwa; "Alamat kitab Kisah Para Rasul sama dengan alamat Injil Lukas yaitu Teofilus (Kisah Para Rasul 1:1). Hal ini sama sekali tidak berarti bahwa tabib Lukas hanya bermaksud untuk menulis kepada seorang pribadi saja. Sebenarnya alamatnya lebih luas. Seperti dalam Inil Lukas, dia mengalamatkan Kisah Para Rasul kepada orang yang berlatar belakang agama kafir, sehingga mereka akan melihat perbuatan-perbuatan Allah dan memuliakannya, iman mereka dikuatkan."7 Kitab Kisah Para Rasul selain dialamatkan kepada Teofilus sebagai laporan tentang perkembangan kekristenan, namun sasaran utamanya kepada orang-orang non Yahudi atau bangsa-bangsa lain yang menganut

\footnotetext{
${ }^{4}$ Ibid hlm. 59

${ }^{5}$ Tim Penyusun Ensiklopedia Alkitab Masa Kini Jilid I, (Jakarta: Yayasan Komunikasi Bina Kasih,

${ }^{6}$ Ibid, hlm 564

${ }^{7}$ Ola Tulluan, Ph.D. Diktat Indtroduksi Perjanjian Baru, hlm. 59.
} 2002) hlm. 652. 
agama kafir untuk dimenangkan menjadi murid Yesus Kristus sebagai tujuan Amanat Agung Tuhan Yesus Kristus (Matius 28:18-20).

Mengenai pribadi Teofilus tim penyusun Ensiklopedi Alkitab Masa kini jilid II menjelaskan bahwa: “Teofilus (Yunani theophilus, 'sahabat Allah'), adalah orang yang kepadanya tabib Lukas mengirimkan kedua tulisan sejarah yang ditulisnya yaitu kitab Injil Lukas dan Kisah Para Rasul (Lukas 1:3; Kisah Para Rasul 1:1)."8 Dalam pengertian etimologi, maka kata Theophilus berasal dari bahasa Yunani yaitu: Kata "theos" yang berarti Allah dan kata "philus" yang berarti sahabat. Maka kata "theophilus" berarti sahabat Allah. Bahkanada orang yang menduga bahwa Teofilus mungkin merupakan nama samaran untuk saudara sepupu Domitian, yaitu Flavius Clemens ${ }^{9}$. Maka kemungkinan Teofilus termasuk golongan bangsawaan yang berjabatan tinggi, sehingga tabib Lukas menyapanya 'yang mulia' sebagai gelar kehormatan. Kemungkinan Teofilus dari golongan bangsawan masyarakat Romawi yang dilayani tabib Lukas demi keuntungan Injil, sehingga sudah menerima sedikit banyak penjelasan tentang agama Kristen. Tetapi tabib Lukas mengambil keputusan untuk menyediakan bagi Teofilus berita yang tersusun rapih dan sistematis dan lebih dapat dipercaya.

Dapat disimpulkan bahwa Teofilus adalah seorang pribadi dari bangsawan Romawi yang berpengaruh dan terhormat dimasyarakat, yang bertobat dari pelayanan dokter Lukas, sehingga membutuhkan informasi yang akurat mengenai perkembangan agama Kristen.

Tanggal penulisan kitab Kisah Para Rasul tidak dinyatakan dengan tepat. Maka mengenai tanggal penulisan yang dimaksudkan dalam penelitian Alkitab adalah tahun penulisan kitab Kisah Para Rasul. "Kisah Para Rasul memang tidak mungkin ditulis dari pada peristiwa terakhir yang dicatatnya, yakni penahanan Rasul Paulus selama dua tahun di Roma (Kisah para rasul 28:30), yang mungkin meliputi tahun 60-61M. ${ }^{10}$ Dalam pengertian bahwa tanggal penulisan kitab Kisah para rasul tidak pada saat Rasul Paulus ditahan sekitar tahun 60-61 masehi. "Tapi kita dapat mencari satu waktu tepat di mana terjadi sesuatu yang menarik perhatian pada agama Kristen dari kalangan anggota masyarakat Roma yang bertanggung jawab seperti Teofilus. Suatu kemungkinan ialah bagian terakhir dari masa kekuasaan Domitian (81-96M) ketika agama Kristen telah memasuki keluarga Kaisar itu."11 Maksud penulis bahwa tanggal atau waktu penulisan kitab Kisah Para Rasul memang penting, namun yang paling penting adalah melalui pelayanan dokter Lukas, agama Kristen telah di bawa dan menyusup masuk ke dalam keluarga kerajaan Romawi. Selanjutnya Ola Tulluan menjelaskan mengenai tanggal penulisan kitab Kisah Para Rasul bahwa: "Tanggal penulisannya dapat ditetapkan kirakira tahun 62-63."12 Dari penjelasan tim penulis ensiklopedia masa kini jilid I dan Ola Tuluan, maka dapat disimpulkan bahwa kitab Kisah Para Rasul ditulis pada akhir tahun

\footnotetext{
${ }^{8}$ Tim Penyusun Ensiklopedia Alkitab Masa Kini Jilid I, hlm 564.

${ }^{9}$ Ibid hlm. 564

${ }^{10}$ Tim Penyusun Ensiklopedia Alkitab Masa Kini Jilid I, hlm 564.

${ }^{11}$ Ibid. hlm 564.

${ }^{12}$ Ola Tulluan, Ph.D. Diktat Indtroduksi Perjanjian Baru, hlm. 60.
} 
62 sampai awal tahun 63, karena tahun 61 rasul Paulus dibebaskan dari penjara di kota Roma, dan kembali melayani memberitakan Injil selama kurang lebih dua tahun.

Kitab Kisah Para Rasul menyambung berakhirnya kitab Injil Lukas, dengan menyampaikan tentang kebangkitan, kenaikan Tuhan Yesus, pencurahan Roh Kudus dan permulaan juga perkembangan gereja mula-mula di Yerusalem (Kisah Para Rasul 1:1 5:42). Selanjutnya kitab Kisah Para Rasul mengisahkan tentang berseraknya orangorang Yahudi yang berbahasa Yunani yang adalah anggota jemaat mula-mula, setelah Stefanus dihukum mati. Peristiwa kematian Stefanus merupakan permulaan pekabaran Injil keluar dari Yerusalem, yang berdampak pada dikisahkannya mengenai pertobatan Saulus yaitu Rasul Paulus, dan pertobatan Kornelius melalui pelayanan Rasul Petrus.

Kitab Kisah Para Rasul mengisahkan tentang pelayanan Paulus sebagai rasul yang bermula dari Paulus bersama Barnabas diutus ke kota Antiokhia. Kisah ini dilanjutkan dengan misi pelayanan penginjilan Rasul Paulus pertama sampai dengan misi yang ketiga. Kitab Kisah Para Rasul memusatkan pemberitaannya pada perjalanan dari Yerusalem ke kota Antikhia dan dari Yerusalem ke kota Roma. Maka iktisar dari kitab Kisah Para Rasul merupakan gambaran awal tentang: (a). Seluruh urutan peristiwa yang terjadi dalam permulaan dan pertumbuhan gereja mula-mula. (b). Peranan para pelaku permulaan dan pertumbuhan gereja mula-mula yang terlibat langsung di dalam peristiwa tersebut. Kedua point tersebut sebagai garis besar atau outline yang menggambarkan tentang pembahasan yang berhubungan dengan keseluruhan permulaan dan pertumbuhan gereja yang dibahas tabib Lukas di kitab Kisah Para Rasul.

Mengenai outline kitab Kisah Para Rasul Merrill C. Tenney membuatnya berdasarkan catatan perkembangannya yaitu: "Iktisar kitab Kisah Para Rasul dapat juga dibuat berdasarkan catatan perkembangannya, yaitu: dalam Kisah Para Rasul 2:47; $5: 14 ; 6: 7 ; 9: 31 ; 12: 24 ; 16: 5$; dan 19:20 tercatat jumlah serta peningkatan mutu kehidupan rohani umat Kristen, yang menunjukkan bahwa Kisah Para Rasul menaruh perhatian pada perkembangan yang progresif dari agama Kristen."13 Pada bagian terakhir dari Kitab Kisah Para Rasul, yaitu: Kisah Para Rasul 19:20 sampai selesai, tekanannya lebih bersifat pribadi dari pada umum. Penekankan peristiwa-peristiwa yang dimaksud yaitu dari kehidupan Rasul Paulus sebagai seorang pribadi bukan gereja sebagai suatu lembaga.

Dari pandangan yang mencatat tentang perkembangan, peningkatan jumlah dan mutu kehidupan rohani umat Kristen mula-mula, maka dapat disimpulkan bahwa kitab Kisah Para Rasul merupakan buku pedoman yang dikhususkan Tuhan bagi pertumbuhan gereja Tuhan sepanjang masa. Namun perlu dicatat bahwa ada pribadipribadi yang dipanggil dan dikhususkan Tuhan untuk pelayanan pertumbuhan gereja mula-mula. Karena itu jika iktisar kitab Kisah Para Rasul dibuat berdasarkan tokohtokoh yang berperan aktif didalamnya maka:

Pertama; Pasal 1:1-5:24 dipusatkan pada Rasul Petrus;

Kedua; Pasal 6-7 dipusatkan pada Stefanus;

${ }^{13}$ Merrill C. Tenney, Survei Perjanjian Baru, (Malang: Gandum Mas, 2009) hlm 285. 
Ketiga; Pasal 8:1-12:25 dipusatkan pada Bernabas, Felipus dan Saulus yaitu Rasul Paulus;

Keempat; Pasal 13:1-28:31 dipusatkan pada Rasul Paulus, sebagai berikut:

Pasal 13:1-28:29; tentang perjalanan missi Rasul Paulus yang pertama.

Pasal 15:1-35; tentang sidang di Yerusalem.

Pasal 15:36-18:22; tentang perjalanan missi Rasul Paulus yang kedua

Pasal 18:23-21:14; tentang perjalanan missi Rasul Paulus yang ketiga

Pasal 21:15-23:10; tentang Rasul Paulus ditawan di Yerusalem.

Pasal 23:11-26:32; tentang Rasul Paulus dipenjarakan di Kaisarea.

Pasal 27:1-28:31; tentang Rasul Paulus dipenjarakan di Roma.

Bila dicermati dengan seksama maka iktisar kitab Kisah Para Rasul berdasarkan para tokoh yang aktif berperan dalam pertumbuhan gereja mula-mula, dapat disimpulkan bahwa para tokoh merupakan teladan bagi pertumbuhan gereja Tuhan sepanjang masa.

\section{Metode Penelitian}

Pada penelitian ini, penulis atau peneliti menggunakan pendekatan atau metode kualitatif untuk memperoleh data yang valid guna membangun sebuah teori yang berkaitan dengan tema atau pokok penelitian. Metode kualitatif yang dimaksud adalah mengkaji dan mengelaborasi setiap sumber, informasi dan data-data yang diperoleh dari pustaka.

\section{Hasil dan Pembahasan}

\section{Peranan Roh Kudus dalam Pertumbuhan Gereja}

Dalam Kitab Kisah Rasul dimungkinkan gerakan pertumbuhan Gereja berawal dari pencurahan Roh kudus. Tuhan Yesus berkata: “Tetapi kamu akan menerima kuasa, kalau Roh Kudus turun ke atas kamu, dan kamu akan menjadi saksi-Ku di Yerusalem dan di seluruh Yudea dan Samaria dan sampai ke ujung bumi", (Roma 1:8). Ayat ini merupakan bunyi gong gereja, di mana gereja tidak lagi hanya ada di Yerusalem. Karena sejak pencurahan Roh Kudus, para Rasul mulai bergerak ke berbagai penjuru bumi untuk membangun gereja. Gerakan para Rasul tidak hanya membangun gereja, tetapi juga menggerakan pertumbuhan gereja melalui gerakan kuasa Roh Kudus untuk menggenapi Amanat Agung Yesus Kristus.

Billy Graham menjelaskan mengenai pribadi Roh Kudus bahwa, Roh Kudus adalah satu pribadi. Yesus tidak pernah menyebut Roh Kudus sebagai "sesuatu." dalam Yohanes 14, 15 dan 16, misalnya, Ia membicarkan Roh Kudus sebagai "Dia” kata ganti orang, sebab Ia bukan suatu kekuatan atau barang, melainkan satu pribadi. ${ }^{14}$ Dalam pemahaman bahwa Roh Kudus adalah oknum yang berpribadi. Karena Alkitab menjelaskan bahwa Roh kudus mempunyai pengetahuan, emosi, kemauan dan kekuatan (Kisah Para Rasul 13:2; Roma 8:26; Wahyu 2:7). Roh kudus adalah satu pribadi yang sangat berperan dalam pelayanan para rasul untuk pertumbuhan gereja mula-mula.

\footnotetext{
${ }^{14}$ Billy Graham, Roh Kudus, Bandung: Lembaga Literatur Baptis, thn. 2000, hlm. 15.
} 
Karena itu pada bagian sangat perlu untuk mengenal pribadi dan peranan dari pada Roh Kudus yang dijanjikan oleh Tuhan Yesus Kristus.

\section{Pribadi Roh Kudus}

Alkitab dengan jelas melaporkan tentang pribadi Roh Kudus yang dijanjikan Yesus Kristus. Kitab-kitab Injil melaporkan peristiwa kematian dan kebangkitan Tuhan Yesus Kristus bertepatan dengan hari raya Paskah orang Yahudi yaitu peristiwa Allah melewatkan orang Israel dari kematian anak sulung dan perbudakan di Mesir, karena percikan darah anak domba yang tidak bercacat celah di ambang pintu kiri, kanan dan atas rumah-rumah orang Israel.

Setelah kebangkitanNya, Tuhan Yesus Kristus menampakkan diriNya sebanyak sepuluh kali kepada para rasul dan para pengikutNya. Empat puluh hari setelah kebangkitanNya, Tuhan Yesus Kristus terangkat kembali ke Sorga disaksikan oleh kurang lebih 120 orang banyaknya (Kisah Para Rasul 1:15) yaitu para rasul dan para pengikut-Nya.

Kitab Kisah Para Rasul melaporkan dengan detail bahwa sepuluh hari setelah Tuhan Yesus terangkat kembali ke Sorga, tepat pada hari raya Pentakosta yaitu hari raya panen gandum yang biasa dirayakan orang Yahudi, terjadi pencurahan Roh Kudus.

Pada hari itu terjadi suatu keajaiban di dalam Bait Allah di Yerusalem yaitu pencurahan Roh Kudus, yang dihadiri dan dialami dengan ke 120 orang yang berkumpul saat itu dengan berbahasa dengan bahasa-bahasa yang lain, tiupan angin keras dan tebaran lidah-lidah api diatas kepala para rasul dan para pengikut Tuhan Yesus Kristus yang berkumpul di Bait Allah saat itu (Kisah Para Rasul 2:1-13).

Peristiwa pencurahan Roh Kudus merupakan penggenapan janji Tuhan Yesus Kristus kepada para rasulNya dan para pengikutNya pada sesaat sebelum terangkat ke Sorga, (Kisah Para Rasul 1:8). Mengenai pribadi Roh Kudus Bruce Milne mengatakan bahwa; Istilah Yunani untuk Roh ialah Pneuma juga mencakup "angin" dan "nafas"15. Kata "angin" dalam pernyataan diatas mengacu kepada "tiupan angin keras" pada peristiwa pencurahan Roh Kudus. Sedangkan kata "nafas" mengacu kepada " ... menghembuskan nafas hidup ..." pada saat penciptaan manusia (Kejadian 2:7).

Pada zaman Perjanjian Baru Roh Kudus lebih jelas peranNya dalam peristiwaperistiwa yang berhubungan dengan kehidupan Tuhan Yesus Kristus. Sebagai contoh; Peranan Roh Kudus terlihat pada saat Maria mengandung Yesus, "Maria mengandung dari Roh Kudus (Matius 1:18); "Roh Kudus akan turun atasmu ...” (Lukas 1:35); "Ia (Simeon) datang ke Bait Allah oleh Roh Kudus" (Lukas 2:25-27). Saat pembaptisan Tuhan Yesus, Roh Kudus muncul "seperti burung merpati" (Matius 3:16) dan sebagainya.

Tentang peran Roh Kudus yang semakin nyata dalam zaman Perjanjian Baru, kembali Bruce Milne mengatakan bahwa; Istilah Parakletos asal kata Yunani atau penghibur pada dasarnya mengacu pada seorang pribadi (Yohanes 14:16) dan lain bandingkan I Yohanes 2:1). ${ }^{16}$ Penghibur yang dijanjikan Tuhan Yesus Kristus adalah Roh

\footnotetext{
${ }^{15}$ Bruce Milne, Mengenal Kebenaran, Jakarta: BPK. Gunung Mulia, 1996, hlm. 244.

${ }^{16}$ Ibid, hlm.244.
} 
Kudus yang menggantikan Tuhan Yesus Kristus untuk selalu bersama para rasul dalam menjalankan Amanat Agung sesuai intruksi yang dicatat dokter Lukas bdalam kitab Kisah Para Rasul 1:8.

Selanjutnya mengenai pribadi Roh Kudus Dr, J. Verkuyl, mengatakan; Roh Kudus bersama-sama dengan Allah Bapa dan Allah Anak adalah Allah yang Esa dan benar, yang layak dipuji dan dimuliakan untuk selama-lamanya ${ }^{17}$. Sedangkan Billy Graham mengatakan; Di dalam Alkitab jelas bahwa Roh Kudus itu adalah Allah sendiri ${ }^{18}$. Pernyatataan-pernyataan tersebut melihat pribadi Roh Kudus dari sifat-sifat Allah Bapa dan Allah Anak yang ada pada Roh kudus yang membuktikan Roh Kudus itu adalah pribadi Allah.

Mengenai peranan Allah Bapa dan Allah Annak dalam mengutus Roh Kudus, Dr. R. Sodarmo berkata bahwa; Kalau kita membaca kitab suci, maka kitab membaca juga bahwa Allah Anak mengambil bagian yang aktif dalam mengutus roh Kudus ${ }^{19}$. Jadi pribadi Roh Kudus tidak hanya utusan Tuhan Yesus Kristus, tetapi juga utusan Allah Bapa. Allah Roh Kudus hadir di dunia menggantikan Tuhan Yesus Kristus atas kehendak dan persetujuan dari pada Allah Bapa. Karena itu Paulus Daun menjelaskan bahwa; Menurut Alkitab jelas bahwa Rooh Kudus mempunyai relasi yang erat antara Allah Bapa dan Tuhan Yesus ${ }^{20}$. Allah Bapa, Allah Anak dan Allah Roh Kudus adalah satu keberadaan yang tak dapat dipisahkan. Dengan demikian, maka tidak ada alasan bagi setiap orang percaya untuk menolak atau tidak menerima Roh Kudus karena Roh Kudus adalah pribadi Allah dan Yesus Kristus sendiri.

Selanjutnya Ichwei G. Indra menjelaskan tentang penyertaan Roh Kudus, yaitu (1). Roh Kudus adalah Allah; (2). Roh Kudus adalah pribadi, dan (3). Roh Kudus adalah pelaksana pekerjaan kristus di dunia ${ }^{21}$. Maksudnya bahwa Roh Kudus adalah pribadi yang datang dari Allah, yang independent yang menyatakan kepribadianNya lewat pekerjaan-pekerjaanNya. Karena Roh Kudus adalah pelaksana mandat Tuhan Yesus Kristus, yang membuktikan eksistensi pribadiNya lewat pekerjaan-pekerjaanNya yang serba ajaib, sejak pencurahan sampai saat ini.

Nama-nama diri Roh Kudus yang erat hubungan dengan Allah, dilaporkan dari ensiklopedia Alkitab masa kini jilid II, bahwa; Alkitab menyebut Roh Kudus juga Roh Allah, Roh kebenaran, Roh Tuhan, Roh Yesus, Roh Penghibur ${ }^{22}$. Nama-nama diri Roh Kudus tersebut membantu menjelaskan tentang indentitas Roh Kudus dalam kesetaraan-Nya dengan Allah Bapa dan Allah Anak.

Selain dari pandang para teolog yang sangat akurat dan Alkitabiah diatas, terlihat juga penjelasan Alkitab tentang kesetaraan Roh Kudus dengan Allah Bapa dan Allah Anak, seperti yang dijelaskan Tuhan Yesus Kristus saat menyampaikan Amanat AgungNya kepada para muridNya. “...baptislah mereka dalam nama Bapa, Anak dan Roh Kudus, ..." (Matius 20:18-20).

\footnotetext{
${ }^{17}$ Dr. J.Verkuyl, Aku Percaya, Jakarta: BPK. Gunung Mulia, 1995, hlm. 166.

${ }^{18}$ Billy Graham, Roh Kudus, Bandung: Yayasan Baptis Indonesia, 2000, hlm 17

${ }^{19}$ Dr.R.Sodarmo, Iktisar dogmatika, Jakarta: BPK Gunung Mulia, 2002,hlm 125

${ }^{20}$ Paulus Daun, Pneumatologi, Manado: Yayasan Daun Family, 2004, hlm. 31

${ }^{21}$ Ichwei G. Indra, Teologi Sistimatika, Bandung: Yayasan Baptis Indonesia, 1999, hlm. 145.

${ }^{22}$ Ensiklopedia Alkitan Masa Kini jilid II, Jakarta: Yayasan komunikasi Bina kasih, 2002, hlm. 318.
} 


\section{Peranan Roh Kudus}

Roh Kudus sebagai pribadi yang berdaulat atas pekerjaanNya yang supranatural, dapat menuntun setiap orang yang bersedia dipimpinNya (Kisah Para Rasul 10:1-48), namun dapat membinasakan setiap orang yang menentangNya (Kisah Para Rasul 5:111). Roh Kudus juga dapat menerangi pikiran manusia (Kisah Para Rasul 8:34-39), yang juga bisa membuat mata manusia menjadi buta (Kisah Para Rasul 9:8). Roh Kudus dapat mengeraskan, membakar dan membinasakan hati, namun dapat melunakan dan memperbaharui hati setiap orang yang menyesali dosa, mengakui dosa dan bertobat dari dosa untuk berpaling kepada Allah.

Pekerjaan Roh Kudus dilakukan di dalam hati yang tersentuh, lewat penjelasan tentang pribadi, kuasa dan kasih dari Allah Bapa dan Allah Anak saat seseorang mendengarkan Firman Tuhan, karena iman timbul dari pendengaran akan Firman Kristus (Roma 1:16-17). Tentang peranan Roh Kudus Ichwei G. Indra menyampaikan bahwa; Alkitab menjelaskan ada tiga macam pekerjaan Roh Kudus: (1). Memberi hidup; (2). Bersaksi tentang kebenaran, (3). Memimpin kita didalam kehidupan Kristen ${ }^{23}$. Bertolak dari pernyataan Ichwei G. Indra tersebut di atas yang memberi pengertian sebagai berikut:

a. Roh Kudus memberi hidup.

Bagian ini bermaksud untuk memberikan pengertian bahwa melalui pekerjaan Roh Kudus seseorang dapat menerima Yesus Kristus menjadi Tuhan dan Juruselamat pribadinya dan memperoleh kepastian untuk memiliki keselamatan atau hidup yang kekal, karena Yesus Kristus adalah jalan kebenaran dan hidup ke kehidupan yang kekal itu.

b. Roh Kudus bersaksi tentang kebenaran.

Dalam pembahasan tentang Roh Kudus bersaksi tentang kebenaran, maka ada empat metode yang dipakai Roh Kudus dalam bersaksi, yaitu:

1. Roh Kudus memberi wahyu yaitu keterangan yang langsung diberikan oleh Allah kepada manusia. Alkitab adalah pewahyuan Allah yang paling nyata dari dan oleh Roh Kudus (II Petrus 1:20-21; II Timotius 3:16).

2. Roh Kudus bersaksi tentang Tuhan Yesus Kristus melalui; orang-orang yang percaya kepada Tuhan Yesus Kristus yang disebut Kristen (Kisah Para Rasul 1:8; 11:26) dan Firman Allah (Ibrani 4:12).

3. Roh Kudus memberi hikmat kepada orang-orang percaya yang berkenan kepada Allah dalam memberitakan Injil dan dalam mengerjakan pekerjaan Allah dalam menunjang pertumbuhan gereja (Kisah Para Rasul 6:3-7).

4. Roh Kudus mengajarkan kebenaran dan mengingatkan tentang segala sesuatu (Yohanes 14:26), seperti; menyakinkan manusia mengenai keperluannya (Yohanes 16:8), memuliakan Tuhan Yesus Kristus (Yohanes 16:13-14) dan mendorong orang untuk percaya kepada Injil (Ibrani 3:7-8).

\footnotetext{
${ }^{23}$ Ichwei G. Indra, Teologi Sistimatika, 1999, hlm. 145.
} 
c. Roh kudus memimpin orang percaya.

Roh kudus memimpin orang-orang percaya di dalam kehidupan Kristen. Karena ketika sesorang menerima Yesus Kristus menjadi Tuhan dan Juruselamat pribadinya, saat itu juga Roh Kudus berdiam di dalam hatinya dan bersedia memimpin hidup untuk hidup seturut kehendak Allah yaitu firman Tuhan. Jadi orang yang dipimpin Roh Kudus adalah orang yang percaya dan mempercayakan hidupnya kepada Allah di dalam Yesus Kristus. Ada dua cara yang dipakai Roh Kudus dalam memimpin orang-orang percaya dalam perjalanan imannya, yaitu:

1. Roh Kudus memimpin dan menolong orang-orang percaya secara pribadi, melalui memberi penghiburan (Yohanes 14:16-18), membantu dalam doa (Roma 8:26), menolong orang-orang percaya untuk beribadah kepada Allah (Efesus 5:18-20) dan memberikan sifat-sifat yang baru kepada oarng-orang percaya (Galatia 5:22-23).

2. Roh memimpin dan menolong jemaat Allah dalam bentuk seperti mengurus gereja setempat (Kisah Para Rasul 13:1-3), anggota jemaat Allah melaksanakan Amanat Agung Tuhan Yesus Kristus (Matius 28:18-20; Kisah Para Rasul 1:8) dan memberikan karunia-karunia Roh Kudus untuk membangun jemaat Tuhan atau gereja Kristus yang adalah tubuh Kristus (I Korintus 12:11,18). Maka tujuan Allah memberikan ke sembilan karunia-karunia Roh Kudus kepada gereja Tuhan, agar jemaat Tuhan saling melengkapi dalam membangun dirinya, sehingga memuliakan Tuhan.

\section{Inti Berita kitab Kisah Para Rasul}

Kitab Kisah Para Rasul memberitakan mengenai kehidupan para rasul Tuhan Yesus Kristus, setelah pencurahan Roh Kudus pada hari raya Pentakosta di loteng Yerusalem. Dengan demikian boleh dipahami bahwa kitab Kisah Para Rasul ini mengungkapkan kisah tindakan supranatural dari Roh Kudus dalam lahir dan bertumbuhnya gereja.

Berita itu benar karena sesaat sebelum Tuhan Yesus terangkat ke Sorga, Tuhan Yesus memperingati para rasul-Nya agar menantikan turunnya Roh Kudus yang telah dijanji-Nya di loteng Yerusalem (Kisah Para Rasul 1:8). Roh Kudus yang dicurahkan sepuluh hari setelah Tuhan Yesus terangkat kembali ke Sorga, dan kemudian berdiam di dalam hati orang-orang percaya (Para rasul), bekerja di dalam hati para rasul untuk memampukan para rasul mengerjakan perintah Amanat Agung dari pada Tuhan Yesus Kristus yang melahirkan gereja-Nya.

Tentang kembalinya Tuhan Yesus Kristus ke Sorga dan pencurahan Roh Kudus serta pelayanan para rasul, Pdt. Ola Tulluan, Ph. D., mengatakan bahwa; Boleh dikatakan kenaikkan-Nya tidak memisahkan Dia dari murid-muridNya. Bahkan Dia baru benarbenar beserta dengan mereka setelah Dia meninggalkan mereka (Yohanes 14:18). ${ }^{24}$ Seperti yang ditekankan dalam Kisah Para Rasul 1:8, dan selanjutnya disampaikan Rasul Paulus kepada jemaat di Korintus dalam suratnya yang pertama (I. Korintus 3:16-17;

\footnotetext{
${ }^{24}$ Pdt. Ola Tulluan, Ph.D., Introduksi PB, t.thn. hlm. 61
} 
6:19-20). Hal ini merupakan upaya Tuhan Yesus Kristus dalam memperlengkapi dan menjadi motor penggerak bagi para rasul saat itu dalam menjalankan Amanat AgungNya sampai saat ini.

Keberanian para rasul dalam tindakan dan perkataan untuk menyampaikan kesaksian saat bersama Tuhan Yesus Kristus dan memberitakan firman Tuhan kepada jemaat mula-mula sangat bermakna karena kekuatan dan kuasa Roh Kudus. Dengan demikian, maka untuk dapat mengerti dan memahami makna kenaikkan Yesus Kristus dan keajaiban dari pada pekerjaan roh Kudus, harus memandang kepada kehidupan para rasul Tuhan Yesus Kristus dari kekuatan dan kuasa Roh Kudus. Maksudnya bahwa kenaikkan kembalinya Tuhan Yesus Kristus ke Sorga justru semakin nyata kekuatan, kuasa penyertaan dan peranan Tuhan Yesus Kristus dalam pelayanan para rasul-Nya, sehingga membawa pertumbuhan yang pesat bagi gereja-gereja mula-mula. Hal ini, karena Roh Kudus yang menggantikan Yesus itu hadir dan menyatu dalam pribadi para rasul, sehingga rasul-rasul yang dulu penakut, setelah dipenuhi Roh Kudus saat peristiwa pencurahan Roh Kudus menjadi pemberani dalam menjalankan Amanat Agung Tuhan Yesus Kristus bahkan diantara para hanya rasul Yohanes yang tidak mati shahit, namun lolos dari penggorengan kaisar Nero dan kemudian dibuang ke pulau Patmos.

Bila dianalisa dalam pendekatan sejarah, Kitab Kisah Para Rasul bertujuan membuat orang-orang Kristen mengerti cara Tuhan Yesus mendirikan Gereja-Nya di dunia ini, dan betapa besar Kasih Karunia Allah kepada bangsa-bangsa lain seperti kepada bangsa Israel. Kitab Kisah Para Rasul merupakan lanjutan dari kitab Injil Lukas, sebab menurut tradisi kedua kitab tersebut ditulis oleh penulis yang sama, yakni Lukas, tabib yang dikasihi dan teman yang menyertai Paulus (Kolose 4:14).

Ds. H. v. d. Brink menjelaskan bahwa; Ada bukti-bukti luar yang lebih jelas lagi, yaitu mulai dari abad ke dua diketahui penulis adalah sama, sesuai dengan bukti-bukti tentang gaya penulisan, maupun pandangan pokok-pokok yang ada dalam Injil Lukas dan Kitab Kisah Para Rasul. ${ }^{25}$ Hal ini sudah dipastikan mengingat Kitab Kisah Para Rasul ini dipersembahkan kepada seorang bernama Teofilus. Bila membaca kitab Lukas 1:1 dan Kisah para rasul 1:1; “... bukuku yang pertama ...” menunjuk kepada Injil Lukas.

Nama Theofilus sendiri, dalam kedua Kitab tersebut adalah orang terkemuka sebab disapa dengan bergelar "yang mulia", gelar yang diberikan kepada wali negeri orang Roma di Yudea, (bandingkan Kisah para rasul 23: 26; 24: 2; 26: 25). Gerhard A. Krodel menjelaskan bahwa; Ia (Teofilus) sudah mengetahui sepintas tentang konsep iman Kristen, dan Lukas ingin memberi keterangan yang lebih tepat, bahwa apa yang diketahui Teofilus tentang iman Kristen patut dipercaya ${ }^{26}$. Melalui laporan-laporan tabib Lukas kepada Teofilus agar sedikit banyak memahami konsep iman Kristen yang saat itu merupakan sekte Yahudi yang semakin pesat perkembangannya, dan bahkan sudah memasuk ke istana kekaisaran Romawi.

${ }^{25}$ Ds.H.v. d. Brink, TAFSIRAN ALKITAB KISAH PARA RASUL (Jakarta, BPK Gunung Mulia, cet. Ke$5,2000)$ hlm. 11

${ }^{26}$ Gerhard A. Krodel, Augsburg Comenntary on The New Testament Acts (Minneapolis, Minnesota, 1986) hlm. 18-19. 
F. F. Bruce menjelaskan bahwa; Lukas menulis sejarah permulaan ke-Kristenan, berisi cerita yang dimulai dari kelahiran Yohanes Pembabtis dan Yesus, sampai kepada akhir Paulus ditahan selama dua tahun di penjara Roma ${ }^{27}$. Salah satu tujuan Lukas untuk menjembatani jurang antara Kristen Yahudi dengan Kristen non-Yahudi, dan menunjukkan bahwa pengabaran Injil kepada non-Yahudi (yang rupanya membuat dirinya menjadi Kristen) adalah perkembangan wajar dari pelayanan Yesus, dan iman Kristen yang berasal dari Yerusalem.

\section{Ajaran-ajaran utama kitab Kisah Para Rasul}

1. Kisah para rasul $1: 1-5: 42$

Dalam pasal-pasal ini pembahasannya berhubungan dengan pengajaran tentang kelahiran Gereja Tuhan Yesus pertama kali (jemaat mula-mula). Bagian ini menceritakan tentang Amanat agung Tuhan Yesus Kristus yang diberitakan kepada murid-murid-Nya sebelum ke naik-Nya ke Sorga. Bagian juga ini banyak menceritakan tentang orang-orang percaya setelah mendengar khotbah Rasul Petrus yang sungguh dikuasai oleh Roh Kudus.

Ada dua hal paling penting ditemukan pada bagian ini menunjuk kepada:

a. Perkataan Tuhan Yesus bahwa murid-murid-Nya akan menerima kuasa setelah menerima Roh Kudus digenapi ketika para Rasul berkumpul di Yerusalem, (Kisah para rasul 1: 8; 2: 1, 36-41).

b. Kehidupan orang-orang percaya pada abad pertama (gereja mula-mula) yang penuh dengan kasih terhadap sesama dan sungguh-sungguh memperlihatkan ketekunannya dalam beribadah kepada Allah, (Kisah para rasul 2: 41-47; 4: 32-37).

\section{Kisah para rasul 6:1-12:24}

Pembahasan dalam pasal-pasal ini berhubungan dengan pengajaran tentang perkembangan Gereja yang berada dalam penganiayaan terhadap orang-orang percaya. Orang-orang percaya di kota Yerusalem mengalami penganiayaan dari orang-orang Yahudi, sehingga melarikan diri dan tersebar ke berbagi penjuru dunia. Tetapi dalam segala penderitaan dan penganiayaan itu para rasul tetap memberitakan Injil Tuhan Yesus.

Ada dua hal yang memerlukan pendalaman tentang hal ini menyangkut:

a. Kisah tentang beratnya penderitaan dan penganiayaan yang dialami orang-orang percaya, yang tidak memutuskan kehidupan dan ketaatannya untuk setia beribadah dan memberitakan Injil, (Kisah para rasul 7:54-8:1-4).

b. Kisah tentang Saulus (rasul Paulus) yang adalah seorang penganiaya orang-orang percaya, mengalami pertobatan dan akhirnya menjadi Rasul Yesus Kristus. Ini mengajarkan bahwa kuasa Roh Kudus mampu mengubah kehidupan seseorang yang sangat jahat dan kejam sekalipun, untuk menjadi berkat bagi sesama, (Kisah para rasul 9: 1-22)

\footnotetext{
${ }^{27}$ F.F. Bruce, The Acts of the Apostle: The Greek Test with Introdution and Commentary, 1952, hlm. 1
} 


\section{Kisah para rasul 13:1-15:41}

Pembahasan pada bagian ini berhubungan dengan pengajaran tentang jemaat (Gereja) setempat yang memberitakan Injil. Di bagian ini dijelaskan tentang kehidupan orang-orang percaya di kota Antiokhia, dan sebutan orang Kristen pertama kali diberikan dan disebutkan kepada murid-murid Tuhan Yesus. Orang-orang percaya di Antiokhialah pertama sekali ada sebutan Kristen atau pengikut Kristus, (Kisah para rasul 11:23-26).

W. Stanley Heath menjelaskan bahwa; Pertumbuhan dan perkembangan orangorang percaya, yang mengutus penginjil-penginjil kepada bangsa-bangsa lain karena taat kepada Roh Kudus. Ini memungkinkan mengajarkan kepada setiap Gereja yang ada sekarang mempunyai beban penginjilan pada setiap orang yang belum mengenal Tuhan Yesus, (Kisah para rasul 13:1-628)29. Jadi dampak dari pertumbuhan gereja secara kualitatif ialah pengutusan untuk memberitakan Injil, sebagai bagian dari upaya menggenapi Amanat Agung Tuhan Yesus Kristus.

\section{Kisah para rasul 16:1-28:31}

Pembahasan dalam pasal-pasal ini tentang pengajaran tentang nama Tuhan Yesus diberitakan ke seluruh dunia. Kasih karunia Allah yang ada di dalam Tuhan Yesus, diberitakan dan disampaikan kepada setiap suku bangsa, baik yang menjadi rakyat biasa maupun yang menjadi tentara atau prajurit dan raja-raja di istana, (Kisah para rasul 23:11) ayat ini adalah perkataan Tuhan Yesus kepada Rasul Paulus untuk bersaksi dengan penuh keberanian di Roma. Ini juga mengajarkan kepada setiap orang Kristen khususnya para pelayanan Tuhan, agar tetap mempunyai keberanian untuk bersaksi kepada setiap orang.

\section{Kitab Kisah Para Rasul sebagai Panduan Pertumbuhan Gereja.}

Melalui Kitab Kisah Para Rasul dapatlah dijadikan sebagai panduan pertumbuhan Gereja sepanjang masa, bahwa perkembangan Gereja Tuhan Yesus dan Kasih Karunia Allah yang diberikan kepada setiap bangsa mendapat tantangan dari kuasa dunia dan orang-orang yang tidak mau mengenal Allah. Tetapi Kemahakuasaan Allah, melalui dan di dalam Tuhan Yesus dengan penuh dinamika Roh kudus Gereja terbangun di atas dasar Firman Tuhan. Tuhan Yesus mengalahkan semua kuasa dunia ini, dan Gereja akan terus bertumbuh menggenapi firman Tuhan.

Model pertumbuhan gereja di dalam kitab Kisah Para Rasul, menjadi format pelayanan pertumbuhan gereja yang dikehendaki Tuhan Yesus Kristus kepala gereja. Format yang dimaksud ialah gereja lahir dari pengajaran firman Tuhan, persekutuan para murid dan pelayanan kasih sebagai kesaksian hidup orang percaya di bawah pengaruh dan di dalam tuntunan kuasa Roh Kudus.

Ir. Timotius Surbekti menjelaskan bahwa; Jika orang percaya dicengkeram kuasa Allah, ia menjadi berani mati dan tidak takut menderita. Ia mencintai Tuhan lebih dari pada dirinya sendiri. Ini yang dibutuhkan Tuhan agar Gereja dapat berkembang dan

\footnotetext{
${ }^{28}$ I. L. Nomensenn, “Benih Yang Bertumbuh”; (Pematang siantar, 1984), hlm. 47-57.

${ }^{29}$ W. Stanley Heath, Penginjilan dan Pelayanan Pribadi (Surabaya, Penerbit Yakin tt). hlm. 34 dst.
} 
bertumbuh. Hati Allah adalah hati missi, makanya Allah mengutus. ${ }^{30}$ Allah telah memberikan kepada orang percaya Roh Kudus yang adalah Roh yang penuh kuasa, Roh yang penuh kasih, Roh yang ketertiban dan bukan roh ketakutan (II Timotius 1:6-8).

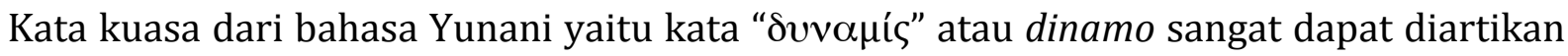
bergerak akan menghasilkan energi. Demikian juga kata " $\mu \alpha \rho \tau u ̈ \rho$ " yaitu saksi atau berani mati dalam bersaksi tentang Yesus Kristus dan kuasa kebangkitan-Nya sebagai inti pemberitaan Amanat Agung.

Roh Kudus yang dicurahkan kepada para rasul dan semua orang percaya, mampu untuk menggerakan dan mampukan para rasul dan semua orang percaya pada segala masa dan tempat untuk berani memberitakan Injil dengan penuh kuasa yang berdampak pada pertumbuhan gereja. Dapat dipahami bahwa lahirnya gereja sematamata merupakan program Allah melalui kuasa dan gerakan Roh Kudus dalam pemberitaan Injil untuk menggenapi Amanat Agung Tuhan Yesus Kristus sebagai dampak dari pertumbuhan gereja sepanjang masa.

\section{Tinjauan Teologis Gereja Dan Pertumbuhannya Berdasarkan Kitab Kisah Para Rasul}

\section{Pengertian}

Kata 'Gereja' merupakan kata yang nampaknya mudah tetapi telah banyak disalah mengerti. Jika kita berbicara tentang Gereja, diakui atau tidak, kita mempunyai asosiasi atau imajinasi tentang suatu institusi gerejawi, organisasi, liturgi, teologia dengan main line Calvinis, Lutheran, Baptis dan sebagainya ${ }^{31}$.

Orang Kristen sendiri masih kurang memahami, bahkan salah mengerti tentang hakekat Gereja yang sesungguhnya. Orang Kristen memahami gereja sebagai bangunan atau denominasi (aliran atau organisasi gereja). Pengertian yang demikian adalah salah. Gereja bukanlah bangunan fisik atau gedung; juga bukan sesuatu deenominasi atau organisasi. Gereja dapat dipahami melalui pengertian istilah, baik yang digali dari bahasa-bahasa gereja Eropa dan juga dari Alkitab sendiri, baik Perjanjian Lama maupun Perjanjian Baru. Memang wajar jika suatu istilah mengalami perkembangan arti (konotasi), namun kedinamisan konotasi tidak boleh menyeleweng dari esensi. Demikian juga dengan Gereja yang telah menempuh perjalanan sejarah gereja mulamula, yang secara "historis" dimulai sejak hari Pentakosta (Kisah Para Rasul 2). Namun perlu dipahami dengan baik, karena tidak berarti bahwa aset Gereja Perjanjian Baru lepas dari Perjanjian Lama.

Oleh karena itu ini penulis secara khusus akan membahas pengertian gereja dan pertumbuhan gereja, dengan melihat perkembangannya dalam masa Perjanjian Lama dan juga dalam Perjanjian Baru.

\footnotetext{
${ }^{30}$ Ir. Timotius Surbekti, Gereja dalam Pendakian Puncak Sejarah Dunia ( Yogyakarta, Penerbit Yayasan Andi, cet. Ke-1, 1987) hlm. 37-38.

${ }^{31}$ Lotnatigor Sihombing, Kultus dan Kultur, Batu: Sekolah Tinggi Theologia I-3, 1997, 6.
} 
Prinsip dasar pengertian gereja dan pertumbuhan Gereja adalah tetap berpegang kepada Alkitab. Alkitab Perjanjian Lama tidak menyebutkan secara jelas suatu teologi pertumbuhan Gereja. Namun melalui Firman Tuhan, sungguh menunjukkan bahwa ada amanat dalam Perjanjian Lama (Kejadian 1:28), "Beranak cuculah dan bertambah banyak". Mandat missi dan mandat budaya bertambah dan bertumbuh memungkinkan terjadinya pertambahan dan pertumbuhan gereja baik secara kualitas maupun kuantitas yaitu memaksimalkan seluruh potensi yang disediakan Allah. Tersirat perkembangan biologis bertambah banyak bagi orang-orang yang menyembah Allah.

Pada Perjanjian Baru ada banyak ayat Firman Tuhan yang menjelaskan tentang pertumbuhan dan pertambahan gereja. Amanat Agung yang sering diidentikkan dan ditujukan dengan Amanat Agung Tuhan Yesus Kristus (Matius 28:18-20) sudah menjadi titik tolak orang percaya untuk pergi memberitakan Injil, mengajarkan Firman Tuhan, dan melaksanakan sakrament (baptis). Dalam Kisah Rasul pasal 2, tentang gerakan pertumbuhan gereja oleh Roh Kudus terdapat tiga gerakan yaitu (a). Gerakan Misi; (b). Gerakan Penginjilan. dan (c). Gerakan Pertumbuhan gereja.

Pertumbuhan gereja yang dimaksud dilihat dari keanggotaan, yaitu: (a). Pertumbuhan gereja secara biologis; (b). Pertumbuhan gereja karena perpindahan; perpindahan daerah dan perpindahan gereja ke gereja; (c). Pertumbuhan gereja karena pertobatan. Kisah Rasul 2: 41-47 yang membahas tentang, gerakan pertumbuhan gereja terjadi sesudah pencurahan Roh kudus. Dengan mengacu kepada pendekatan historis, pertumbuhan dan pertambahan Gereja, melalui pemberitaan Injil, pengajaran firman oleh para rasul dan pembaptisan orang percaya yang bertobat.

\section{Pengertian gereja}

Secara umum gereja dapat diartikan gedung tempat orang Kristen beribadah atau organisasi yang memberikan legalitas secara hukum negara. Dengan demikian, maka pada bagian ini akan penulis membahas pengertian gereja dari perspektif Alkitab maupun para teolog.

\section{Pengertian gereja dari perspektif para teolog.}

Christ Marantika menjelaskan tentang pengertian gereja, bahwa; "Kata gereja bila diselidiki maka menurut bahasa Yunani dari kata 'Ekklesia' yang berarti orang-oraang yang dipanggil keluar dari kegelapan dosa oleh Injil Yesus Kristus untuk datang kepada terang ajaib."32 Maka menurut ajaran Alkitab, arti gereja tidak menunjuk kepada gedung tempat ibadah, atau suatu aliran gereja. Gereja adalah orang-orang yang telah dipanggil keluar dari dunia oleh Injil Yesus Kristus dan disatukan oleh iman dalam Injil Yesus Kristus untuk melakukan kehendak Allah.

Menurut Suhento Liauw yang menjelaskan pengertian gereja sebagai berikut; "Kalau saja kata gereja diselidiki, maka secara tertulis tidak ditemukan dalam Alkitab. Kata 'Gereja' berasal dari bahasa Portugis "Igreya” sedangkan kata jemaat berasal dari bahasa Arab 'Jemaah'. pengertian ini sama dengan makna kata gereja dalam bahasa

${ }^{32}$ Christ Marantika, Kepercayaan dan Kehidupan Kristen, (Jakarta: BPK. Gunung Mulia, 1984) hlm. 
Inggris yang memiliki dua ungkapan yaitu 'Church' dan Assembly'. Kata 'church' dipakai untuk menunjukkan gedung. Kalau kata 'Assembly' dipakai untuk menunjukkan pada orang-orangnya. Apabila disejajarkan dalam bahasa Indonesia, 'church' adalah gereja dan assembly adalah 'jemaat'. ${ }^{33}$ Pernyataan ini dapat dipahami bahwa pengertian gereja dapat dipahami sebagai tempat ibadah atau persekutuan dan gereja yang adalah orangorang percaya yang hidup dalam persekutuan dengan Tuhan Yesus Kristus.

J. L. Ch. Abineno menguraikan pengertian gereja sebagai berikut; "Gereja adalah suatu perkumpulan manusia biasa, yang mempunyai kesamaan-kesamaan tertentu dengan lembaga-lembaga kemasyarakatan di dunia seperti negara, partai politik, perkumpulan sosial dan lain-lain. Tetapi kalau kita lihat dari sisi hakekatnya, ia pada lain pihak adalah suatu persekutuan rohani dengan Yesus Kristus sebagai kepala . Sebagai persekutuan rohani ia adalah objek dari percaya atau iman kristen". ${ }^{34}$ Jadi secara hukum, gereja adalah organisasi yang penatalayanannya tidak berbeda dengan organisasi-organisasi pada umumnya, tetapi yang membedakan hanyalah objektivitas gereja yang berfokus pada pembinaan iman kristen lewat peningkatan persekutuan bersama Tuhan Yesus Kristus. Oleh karena itu, maka sikap hidup Tuhan Yesus Kristus harus menjadi cermin atau teladan bagi kehidupan orang-orang kristen, dan menjadi kitab yang terbuka bagi semua orang melihat hidup dan sikap Tuhan Yesus Kristus.

Selanjutnya Ron Jenson \& Jim Stevens mengatakan bahwa; pertumbuhan gereja adalah pertumbuhan yang seimbang dalam kualitas, kuantitas, dan kompleksitas organisasi sebuah gereja lokal. ${ }^{35}$ Defenisi ini merupakan kunci untuk memahami proses yang menyebabkan gereja bertumbuh. Jika ketiga komponen pertumbuhan gereja yaitu kualitas, kuantitas, dan kompleksitas organisasi tidak terjadi secara seimbang dalam sebuah gereja lokal, maka gereja lokal tersebut tidak akan bertumbuh dengan sehat dan baik.

Misalnya pertumbuhan gereja hanya secara kuantitas, dengan mengorbankan pertumbuhan kualitas dan kompleksitas organisasi, maka gereja tersebut tidak bertumbuh secara sehat seimbang. Selanjutnya Ron Jenson \& Jim Stevens menjelaskan bahwa, Pertumbuhan gereja adalah segala sesuatu yang terlibat dalam membawa pria dan wanita yang tidak memiliki hubungan pribadi dengan Yesus Kristus masuk kedalam persekutuan dengan-Nya ke dalam keanggotaan gereja yang berbertanggung jawab. ${ }^{36}$ Dalam hal ini, maka pertumbuhan gereja yang sehat dan seimbang ialah bertumbuh secara kualitas baik dalam pengetahuan firman Tuhan, iman dan karakter yang merujuk pada perubahan hidup dan karakter kepala gereja yaitu Tuhan Yesus Kristus.

Bila dipahami pengertian gereja yang sesungguhnya, dari sudut pandang yang Alkitabiah, maka; Gereja adalah persekutuan orang-orang yang dipilih, dipanggil oleh Allah keluar dari kegelapan (dosa) kepada terang yang ajaib yaitu Tuhan Yesus Kristus, dan ditempatkannya di dunia ini untuk melayani Allah dan manusia melalui memberitakan perbuatan-perbuatan Allah yang ajaib dan besar (I Petrus 2:9-10). Dari

\footnotetext{
${ }^{33}$ Suhento Liauw, Doktrin Gereja Alkitabiah, (Jakarta: Graphe, 1996), hlm. 43-44.

${ }^{34}$ J. L. Ch. Abineno, Garis-garis Besar Hukum Gereja, (Jakarta: BPK. Gunung Mulia, 1994), hlm. 2-3.

${ }^{35}$ Ron Jenson \& Jim Stevens, Dinamika Pertumbuhan Gereja (Malang : Gandum Mas, T. thn.), hlm, 8.

${ }^{36}$ Ibid, hlm 9.
} 
ayat ini Rasul Petrus mendefenisikan gereja sebagai persekutuan orang-orang percaya yang sudah ditebus Allah dengan darah Tuhan Yesus Kristus untuk mengerjakan Amanat Agung Tuhan Yesus Kristus agar semua manusia diselamatkan bagi kemuliaan Allah. Bagian inilah yang kemudian dikenal dengan istilah hukum keselamatan yaitu melalui karya penyelamatan oleh Tuhan Yesus Kristus di kayu salib Allah menghendaki agar semua manusia diselamatkan dari dosa dan kematian kekal, sehingga diberikan Amanat Agung-Nya di dalam Injil Matius 28:18-20. Namun fakta keselamatan ialah hanya setiap orang mengaku dengan mulut dan percaya dalam hati (Roma 10:9-10), serta menerima Yesus Kristus menjadi Tuhan dan Juruselamat pribadi dalam hidupnya (Yohanes 1:12), selanjutnya terus belajar untuk hidup sesuai keteladanan hidup Yesus Kristus (Filipi 2:1-11) yang diselamatkan.

Sedangkan pengertian gereja menurut tim penyusun Kamus Besar Bahasa Indonesia adalah: (1). Gedung (rumah) tempat berdoa dan melakukan upacara orang Kristen, (2). Badan (organisasi) umat Kristen yang sama kepercayaan, ajaran dan tata cara ibadahnya. ${ }^{37}$ Maksud defenisi ini bahwa Gereja selalu dipandang dari bangunan fisik atau gedung yang diperuntukan sebagai tempat persekutuan atau tempat beribadahnya orang-orang Kristen atau tebusan Kristus. Sedangkan pengertian gereja dari sudut pandang sebagai organisasi, berfungsi memberikan jaminan kepastian hukum yang mengelola atau memagement petalayanan gereja Tuhan agar terencana dan sistematis dalam memberitakan Injil menjangkau jiwa-jiwa dan menggembalakan jiwajiwa yang sudah dimemangkan bagi-Nya.

Sedang menurut Christ Marantika, pengertian tentang gereja bahwa, Gereja adalah orang-orang yang telah dipanggil keluar dari dunia oleh Injil Yesus Kristus disatukan oleh iman dalam Yesus Kristus untuk melakukan kehendak Allah. ${ }^{38}$ Pengertian dari pernyataan diatas dapat dipahami bahwa menurut ajaran Alkitab, arti gereja tidak menunjuk kepada gedung tempat ibadah, atau suatu aliran tertentu. Karena gereja yang sesungguhnya adalah kumpulan orang-orang percaya yang telah ditebus oleh Allah dengan darah Kristus. Dengan demikian gedung gereja boleh dihancurkan, organisasi gereja boleh dibubarkan, tetapi esensi gereja akan tetap ada dan berjalan sebab gereja itu organisme yang walau semakin dihambat akan semakin merambat.

Gereja merupakan organisme yang hidup, maka segala sesuatu tentang gereja melibatkan Yesus Kristus kepala gereja yang adalah juruselamat yang hidup. Gereja termasuk individu yang dihidupkan secara rohani sebagai akibat dari kelahiran baru (Yohanes 3:3; Efesus 2:1-3 ). Gereja baik secara organisme maupun secara lembaga, gereja dipenuhi dan didiami Roh Kudus yang hidup (Yohanes 14:6; I Korintus 3:16-17). Pekerjaan gereja dituntun oleh firman Tuhan yang menghidupkan ( Ibrani 4:12). Dengan demikian, maka gereja berdenyut seiring kehidupan Tuhan Yesus Kristus, sehingga gereja terus bertumbuh walaupun mengalami berbagai hambatan dan tantangan dari waktu ke waktu sampai kedatangan Tuhan Yesus Kristus kepala gereja.

Selanjutnya untuk menegaskan bahwa fungsi gedung gereja juga penting manfaatnya dalam pelaksanaan kegiatan gereja, maka Dr. J. Verkuyl mengatakan bahwa:

\footnotetext{
${ }^{37}$ Tim Penyusun, Kamus Besar Bahasa Indonesia.

${ }^{38}$ Christ Marantika, Kepercayaan dan Kehidupan Kristen, (Jakarta, BPK. Gunung Mulia, 1984) hlm. 183.
} 
Gereja adalah lahir dari Allah. Buah tangan pekerjaan Roh Kudus. Hal yang terpenting dalam gereja ialah penyataan Allah, pemilihan oleh Allah, kehendak Allah untuk mengumpulkan orang-orang beriman. ${ }^{39}$ Dari pendapat kedua teolog tersebut di atas dapat dipahami, bahwa gereja sebagai persekutuan orang-orang percaya membutuhkan tempat dan organisasi untuk beribadah sebagai wujud persekutuan dengan Allah dan sesama juga menata pelayanan gereja kearah kesempurnaan yang dikendaki Kristus Yesus.

Mengenai penatalayanan gereja J. L. Ch. Abineno mengemukakan, bahwa: Gereja adalah suatu perkumpulan manusia biasa, yang mempunyai kesamaan-kesamaan tertentu dengan lembaga-lembaga kemasyarakatan di dunia seperti Negara, partai politik, perkumpulan social dan lain-lain. Tetapi kalau kita melihat dari sisi hakekat, ia pada lain pihak adalah suatu persekutuan rohani dengan Yesus Kristus sebagai kepala. Sebagai persekutuan rohani, ia adalah "objek dari percaya ataui iman Kristen". 40 Bila dipandang dari sisi hukum, maka gereja adalah organisasi yang penatalayanannya tidak berbeda dengan organisasi pada umunya. Perbedaan hanya pada objektivitas gereja yang berfokus pada pembinaan iman Kristen, untuk mencerminkan kehidupan dan karakter Yesus Kristus agar menjadi kitab yang terbuka, untuk dapat dibaca oleh semua orang.

Dari pandangan-pandang dan uraian tersebut diatas, dapat dipahami dan diberi kesimpulan sementara bahwa ada tiga pengertian gereja, sebagai berikut:

a. Gereja dalam pengertian sebagai persekutuan orang-orang yang dipilih dan dipanggil Allah keluar dari kegelapan dosa kepada terang yang ajaib yaitu Tuhan Yesus Kristus.

b. Gereja dalam pengertian sebagai bangunan atau gedung tempat persekutuan orangorang tebusan Tuhan Yesus Kristus dengan Allah dan dengan sesama.

c. Gereja dalam pengertian organisasi yaitu badan hukum yang menaungi gereja dalam pemerintahan dunia, dan untuk mengatur penatalayanan gereja agar pelayanan gereja terencana dan sistematis dalam upaya mencapai tujuan dan fungsi gereja.

\section{Pengertian gereja dari prespektif Alkitab}

Pengertian Gereja secara theologis Alkitabiah ialah bahwa Gereja (ekklesia) itu adalah tubuh Yesus Kristus (Efesus 1:22-23) dan Yesus Kristus adalah kepala gereja. Karena orang-orang percaya adalah kumpulan-kumpulan orang-orang yang dipanggil oleh Tuhan Yesus Kristus, maka Gereja berasal dari Tuhan Yesus Kristus sendiri yang adalah kepala bagi gereja itu sendiri.

\section{Pengertian gereja dalam Perjanjian Lama}

Mungkin akan muncul pertanyaan, apakah di dalam Perjanjian Lama sudah ada gereja? Jika asumsinya tentang gereja sebagaimana yang berkembang pada masa kini, kemungkinan akan berkata bahwa di dalam Perjanjian Lama belum ada gereja,

\footnotetext{
${ }^{39}$ Dr.J.Verkuyl, Aku Percaya, (Jakarta: BPK. Gunung Mulia, 1995) hlm. 199.

${ }^{40}$ J.L.Ch. Abineno, Garis-garis Besar Hukum Gereja, (Jakarta, BPK. Gunung Mulia, 1994) hlm. 2-3.
} 
sebagaimana pandangan para pemikir modern. Namun di dalam Perjanjian Lama terdapat ada dua istilah, yang menggambarkan tentang umat Tuhan yang menunjuk kepada Gereja, yaitu qahal (atau kahal) yang diturunkan dari akar kata yang sudah tidak dipakai lagi yaitu qal (atau kal), yang artinya "memanggil"; dan 'edhah yang berasal dari kata ya'adh yang artinya "memilih" atau "menunjuk" atau "bertemu bersama-sama di satu tempat yang ditujuk"41. Kedua kata ini kadang-kadang dipakai tanpa dibedakan artinya. 'Edhah adalah kata yang lebih sering dipakai dalam Keluaran, Imamat, Bilangan dan Yosua, tetapi tidak dijumpai dalam kitab Ulangan, dan jarang dijumpai dalam kitabkitab selanjutnya dalam Perjanjian Lama. Kata qahal banyak sekali dijumpai dalam Tawarikh, Ezra dan Nehemia.

Istilah qahal biasanya diterjemahkan menjadi jemaat, sedangkan 'edhah diterjemahkan menjadi umat. Septuaginta, menerjemahkan qahal ini dengan ekklesia. Qahal ini juga digambarkan dengan kemampuan berperang sebagaimana dapat ditemukan dalam kitab Ester 8:11, 9:2, 15, 16, 18 dan yang tak asing di dalam kitab Hakim-Hakim. ${ }^{42}$ Masih banyak refleksi lainnya dalam ragam penggunaan istilah ini, termasuk dalam pengertian beribadat. Hal ini menunjukkan variabilitas keadaan jemaatNya. Jemaat adalah umat Allah, dikuduskan, diurapi dan harus mendengarkan hukum Allah. Sedangkan istilah 'edhah, mempunyai pengertian perkumpulan yang sudah ditetapkan. Apabila hal ini dikenakan kepada umat Israel, maka hal ini menunjuk kepada para pemimpin agama, baik yang sedang berkumpul maupun tidak. Karena itu pada umumnya dua kata dipakai bersama-sama dengan qahal, sehingga menjadi qahal'edhah yaitu jemaat sedang berkumpul. Karena itu dapat disimpulkan bahwa umat Allah, qahal-'edhah yang mendasari pengertian gereja sebagai umat Tuhan mempunyai karakter:

1. Mendengar hukum (Ulangan 4:10; 9:10; 18:16, dst.).

2. Mempunyai pertahanan bersama (Ester 8:11; 9:2, 15-16, 18), dapat berperang (Yosua 22:12; Hakim-hakim 20:1).

3. Berdiri di hadapan Allah (Ulangan 4:10; 1Raja-raja 12:21) yang dikuduskan, diurapi, dan mendengar firman Allah.

4. Memberikan persembahan domba Paskah (Keluaran 12:1-28).

5. Menerima perjanjian Allah (Keluaran 33:1-35:29).

6. Kepadanya Allah memberikan penebusan dan menerima kurban penebusan karena Allah (Imamat 4:16).

7. Mendapat sebutan sebagai bangsa yang kudus dan memuliakan Allah (Keluaran 19:6; Hosea 2:23; Mazmur 2:23; 22:22 bandingkan dengan Ibrani 2:9, 10).43

${ }^{41}$ Louis Berkhof, Teologi Sistematika: Doktrin Gereja Lembaga Reformed Injili Indonesia, Momentum, Surabaya, 1997, 5.

${ }^{42}$ Edmund P.Clowney, The Church Leicester: Inter Varsity Press, 1995, 30.

43 William Childs Robinson, “Church,” dalam Baker's Dictionary of Theology, ed. Everett Harisson Grand Rapids: Baker Book House, 1981, 123. 
Bangsa Israel mendapat predikat umat Allah dan jemaat Allah karena bangsa Israel dipilih dan dikuduskan oleh Allah. Hubungan Allah dengan bangsa Isarel umatNya sedemikian intim, sehingga banyak gambaran di dalam Perjanjian Lama yang mengungkapkan bagaimana intimnya hubungan Allah dengan umat-Nya itu. Ini menunjukkan bahwa pemulihan relasi, rekonsiliasi dan persekutuan dengan Allah bukan teori melainkan realitas. Pemilihan-Nya untuk rencana keselamatan di muka bumi adalah realitas di dalam sejarah. Allah Yang Maha Tinggi bersedia dan telah turun untuk bersekutu dengan umat-Nya di bumi.

Pengertian dasar Gereja menurut Perjanjian Lama dapat juga dilihat dari sikap dan relasi Tuhan Yesus dengan Israel. Tuhan Yesus datang ke dunia sebagai orang Yahudi, kepada orang Yahudi dan menerima otoritas Perjanjian Lama. Tuhan Yesus menghadiri upacara-upacara dalam Bait Allah dan juga ibadah di sinagoge-sinagoge, serta hidup sebagai orang Yahudi dalam kultur Yahudi. Konsep tentang orang percaya sebagai "Israel yang benar" hanya dapat dimengerti dari latar belakang Perjanjian Lama. Secara ringkas dapat dikatakan bahwa ada kontinuitas Perjanjian Lama dalam Perjanjian Baru.

Pembahasan tentang gereja tidak ditemukan di dalam Alkitab Perjanjian Lama. Walaupun demikian, kegiatan gereja sudah ada dan berjalan dengan baik di zaman Perjanjian Lama, meskipun mungkin berbeda tata ibadah dan penatalayanannya dalam organisasi gereja Perjanjian Baru sampai saat ini. Kegiatan gereja dalam Alkitab Perjanjian Lama terlihat dalam tempat peribadahan orang Yahudi yaitu kemah suci atau Tabernakel pada zaman Musa, Kemah atau pondok Daud pada zaman raja Daud dan Bait Allah di Yerusalem pada zaman raja Salomo serta Sinagoge bagi orang-orang Yahudi diaspora.

\section{Kemah Suci.}

Sebelum Allah Abraham, Ishak dan Yakub memerintahkan Musa membuat Kemah Suci atau Tabernakel, para leluhur bangsa Israel mempersembahkan korban bakaran kepada Allah diatas tugu berupa susunan batu yang disebut mesbah (Kejadian 22:9). Tentang Kemah Suci atau Tabernakel maka, Jusuf B.S. mengatakan: Kata Tabernakel tidak terdapat dalam Alkitab bahasa Indonesia. Kata ini berasal dari kata Tabernacle dalam Alkitab bahasa Inggris. Kata Tabernacle berasal dari dua kata bahasa Ibrani yaitu kata Ohel yang berarti tanda/kemah dan kata Mishkan yang berarti tempat kediaman. ${ }^{4}$ Dalam perjalanan bangsa Israel dari Mesir menuju ke negeri Kanaan, Allah memerintahkan Musa untuk membangunkan Kemah Suci (Keluaran 25:8). Perlunya kemah suci bagi orang Isarel ialah sebagai bukti kehadiran Allah nenek moyang bangsa Israel ditengah-tengah bangsa Israel, ini sebagai bukti adanya persekutuan antara Allah dengan umaNya.

Kemah Suci atau Tabernakel adalah tempat kediaman Allah diantara umat-Nya, yang merupakan upaya Allah untuk membangun persekutuan dengan umat-Nya bangsa Israel. Hal inilah merupakan rahasia kekuatan hidup bangsa Israel sebagai umat pilihan

\footnotetext{
${ }^{44}$ Jusuf B.S., Kemah Suci, (Surabaya, n.p. 1994), hlm. 17-18
} 
Allah. Sebab tanpa kehadiran dan persekutuan Allah dengan bangsa Israel umat pilihanNya itu, tidak mungkin bangsa bangsa Israel bertahan hidup selama empat tahun dalam pengembaraan di padang gurun. Maka begitu pentingnya makna kehadiran Kemah suci bagi umat Allah, untuk kegiatan persekutuan atau ibadah bagi bangsa Israel sebagai wujud kehadiran Allah di tengah-tengah bangsa itu. Hal ini penting, karena di dalam Kemah Suci itulah umat Allah bertemu dengan Allah, dan memperoleh petunjuk dari Allah serta mendapatkan kekuatan baru dalam perjalanan menuju ke tanah Kanaan yang telah dijanjikan Allah dengan sumpah kepada Abraham, Ishak dan Yakob nenek moyang bangsa itu. Mengenai Kemah Suci Ensiklopedi Alkitab Masa Kini jilid I, menjelaskan bahwa: Sebelum Kemah suci didirikan, kita membaca tentang Kemah Pertemuan, yakni suatu tempat perjumpaan sementara dari Allah dengan umat-Nya (Keluaran 33:7-11). Sarana 'Kemah Suci' yang berarti tempat kudus, dapat dibawabawa, dan itulah tempat tinggal Allah ditengah-tengah bangsa Israel di padang gurun. ${ }^{45}$ Sarana yang dimaksudkan ialah kemah suci itu masih dipakai lama sesudah bangsa Israel masuk tanah Kanaan. Pada zaman Hakim-hakim kemah suci yang disebut tempat kudus itu ada di Silo (Yosua 18:1), pada pemerintah raja Saul kemah suci dipindahkan ke Nob (I Samuel 21:1-9; Markus 2:25-26), dan di kemudian hari dipindahkan ke Gibeon (I Tawarikh 16:39). Akhirnya ditempatkan dan diganti oleh raja Salomo dengan mendirikan Bait Suci (Bait Allah) di Yerusalem (I Raja-raja 4:8).

Kemah Suci dibangun karena tujuan Allah yaitu untuk Allah berjumpa dan bersekutu dengan umatNya yaitu bangsa Israel. Dengan demikian Kemah suci terusmenerus ada bagi orang Israel sampai pada zaman Salomo membangun rumah khusus sebagai pengganti Kemah Suci yang dikenal sebagai Bait Allah. Kemah Suci yang kemudian menjadi Bait Allah tidak hanya sebagai tempat persekutuan Allah dengan umat-Nya, tapi juga merupakan nillai perlambangan kehadiran Allah di tengah-tengah bangsa pada zaman itu, karena zaman Kemah Suci merupakan gambaran kehadiran Allah dari Sorga (Ibrani 8:5; 9:9,24).

\section{Bait Allah.}

Pada Zaman raja Salomo tempat ibadah bangsa Israel yang dulu disebut Kemah suci diganti dengan membangun rumah khusus untuk perjumpaan dan persekutuan Allah dengan umat-Nya, yang disebut disebut Bait Allah. Bait Allah yang didirikan oleh raja Salomo di Yerusalem kemudian menjadi pusat kegiatan bangsa Israel. Selain itu, Bait Allah juga menjadi icon kebanggaan bangsa Israel, sebab menjadi lambang kediaman dan kehadiran Allah di tengah-tengah bangsa itu.

Namun kebanggaan tersebut hanya kenangan, karena pada tahun 586 sebelum masehi, bangsa Babel dibawa kekuasaan raja Nebukadnezar menguasai bangsa Yehuda, dan Bait Allah lambang kehadiran Allah dan kebanggaan bangsa Israel dihancurkan oleh tentara-tentara Babel. Selanjutnya bangsa Israel diangkut ke negeri Babel sebagai bangsa tawanan atau bangsa buangan selama 70 tahun. Setelah 70 tahun berlalu, bangsa Yehuda dikembalikan dari pembuangan, dan Bait Allah dibangun kembali dibawah

\footnotetext{
${ }^{45}$ Tim Penyusun, Ensiklopedi Alkitab Masa Kini, (Jakarta, OMF, 2002), hlm. 539.
} 
pimpinan Zerubabel dan Nehemia (Nehemia 2:11-6:19) pada tahun 515 sebelum Masehi.

Pengertian Bait Allah menurut kamus Alkitab ialah: Bait Suci itu menjadi pusat hidup keagamaan umat Yahudi, juga pada zaman Tuhan. Orang-orang Kristen pertama masih turut beribadah disitu, tetapi karena kelamaan terjadi perpisahan antara mereka dengan orang-orang Yahudi (bd. Kis.). Bait Suci itu dimusnahkan pada tahun 70 Ses. Mas. Oleh tentara Romawi di bawah Jenderal Titus. ${ }^{46}$ Jadi bait Allah selain sebagai pusat berbagai kegiatan keagamaan Yahudi, yang menjadi kebanggaan orang Israel selain Tabut Allah, karena merupakan tempat kehadiran Allah diantara umatNya. Namun perlu dipahami bahwa kehancuran bangsa Yehuda bermula dari penyimpangan fungsi Bait Allah.

Ensiklopedi Alkitab Masa Kini jilid I menjelaskan tentang Bait Allah sebagai berikut: Sesudah Israel berkembang menjadi suatu bangsa dirasakanlah perlunya suatu tempat ibadah pusat, dan merupakan keharusan sebagai tempat berkumpul bagi seluruh umat itu, sebagai lambang kesatuan mereka beribadah kepada Allah mereka. Kebutuhan dipenuhi oleh Kemah Suci selama pengembaraan di padang gurun, dan tempat-tempat ibadah yang diakui selama zaman para hakim ${ }^{47}$. Betapa pentingnya kebutuhan akan tempat persekutuan dengan Allah bagi bangsa Israel, yang dilambangkan dengan Kemah Suci dan tempat-tempat ibadah yang diakui selama zaman para hakim seperti di Silo. Hal ini tercermin dalam kehidupan Daud raja Israel kedua.

Alpanya suatu tempat ibadah bagi Yahweh serasa menggelisahkan hati, tatkala Daud sudah mempersatukan seluruh kekuasaannya dan sudah membangun baginya sendiri istana besar dan menetap, Raja Daud berkata; Lihatlah, aku ini diam dalam rumah kayu aras, padahal Tabut Allah diam dibawah tenda (II Samuel 2:7). Tapi izin tidak diberikan kepadanya untuk membangun Bait Suci sebab tangannya dinodai oleh darah musuh-musuhnya, namun bahan-bahan dikumpulkannya, harta ditumpuknya dan tanah untuk tempat Bait Allah dibelinya (I Tawarikh 22:8; II Samuel 24:18-25). Pembangunan Bait Suci dimulai oleh raja Salomo. ${ }^{48}$ Pernyataan ini menggambarkan bahwa walaupun dosa berkuasa atas manusia, namun kerinduan manusia akan persekutuan dengan Allah penciptanya tetap ada. Ini karena adanya kekosongan dihati manusia yang harus dipenuhi dengan kuasa yang lebih tingggi dari dirinya.

Dalam hal ini, gereja sebagai lanjutan dari kemah suci dan bait Allah, harus mampu memberi pemahaman yang Alkitabiah kepada orang-orang percaya agar memberi kekosongan hatinya untuk diisi oleh Tuhan. Adanya penyembahan berhala dan agama-agama suku, merupakan gambaran dari gereja tidak mampu memberi pemahaman yang Alkitabiah juga gaya hidup yang tidak menjadi kesaksian bagi masyarakat diluar gereja.

\footnotetext{
${ }^{46}$ Tim penyusun Kamus Alkitab, (Bogor, LAI, 2007), hlm 424

47 Tim Penyusun, Ensiklopedi Alkitab Masa Kini jilid I, (Jakarta: OMF, 1994), hlm. 136.

${ }^{48}$ Ibid, hlm. 136.
} 


\section{Pengertian gereja dalam Perjanjian Baru}

Nama Gereja berasal dari kata Yunani kuriakos (arti: kepunyaan Tuhan), yang merupakan asal usul dari kata igreia (Latin), dalam bahasa Inggris church dalam bahasa Jerman kirche, dalam bahasa Swedia kyrke, bahasa Slavia cerkov, bahasa Scot kirk; dan bahasa Belanda kerk. Di dalam Perjanjian Baru kata yang dipakai untuk menyatakan pengertian jemaat Tuhan adalah kata yang diambil dari Septuaginta yaitu ekklesia (I Petrus 2:9) diawali dengan preposisi ek yang berarti "keluar dari", dan kata kaleo menjelaskan mengenai "dipanggil keluar dari kounitas tertentu", dan kata sunagoge, dari kata sun dan ago yang berarti "datang atau berkumpul bersama" (Omanson1984:231) ${ }^{49}$. Istilah ekklesia dalam Perjanjian Baru secara umum juga menunjuk kepada Gereja, walaupun dalam beberapa bagian menunjukkan pertemuan secara umum (Kisah para rasul 19:32,39,41), ${ }^{50}$ biasanya kata ini diapakai dalam konteks pemanggilan penduduk Yunani, keluar dari rumah mereka berkumpul dalam suatu tempat yang sudah ditentukan.

Gereja pada jaman perjanjian ini pada dasarnya satu dengan Gereja dari jaman sebelumnya. Sejauh natur esensialnya terkait, keduanya terdiri dari orang-orang percaya yang benar. Pada zaman Perjanjian Baru, Gereja dipisahkan dari kehidupan nasional bangsa Israel dan menjadi organisasi yang tidak terikat kepada bangsa itu. Dalam hubungannya dengan hal ini, batasan-batasan dari Gereja disingkirkan. Apa yang semula merupakan gereja nasional sekarang memiliki sifat universal, penyembahan ritual pada masa lampau menjadi suatu ibadah yang lebih bersifat spritual yang selaras dengan maksud-maksud yang lebih dalam dari Perjanjian Baru.

Dalam Septuaginta "jemaat" diterjemahkan sebagai ekklesia. Suatu istilah yang sudah umum dalam konteks Yunani yaitu sidang parlemen atau sidang rakyat, yang biasanya diadakan di Athena pada hari-hari besar, dan dihadiri oleh para wakil rakyat dan penduduk segenap negeri. ${ }^{51}$

Dalam Perjanjian Baru kata ekklesia, misalnya terdapat dalam Matius 16:18; 18:17. Kedatangan Tuhan Yesus ke dunia memang bukan untuk membawa istilah-istilah baru, melainkan untuk menyelamatkan manusia berdosa. Istilah-istilah yang sudah ada, yang sudah dikenal, dipakai dengan pengertian dan isi yang baru. Pengakuan Petrus di dalam Matius 16:16 yang menjadi dasar didirikannya ekklesia di muka bumi ini adalah berdasarkan penyataan Allah. Dalam gereja yang mula-mula, menurut komentar I. Howard Marshall, Lukaslah yang pertama kali memakai istilah ekklesia untuk Gereja dalam Kisah Para Rasul 5:11 untuk menyatakan kumpulan orang Kristen ${ }^{52}$. Dengan

${ }^{49}$ I. Howard Marshall, The Tyndale New Testament Commentary, The Acts of the Apostles, Michigan:

Williams B. Eerdmans Publishing Company, 1980.

${ }^{50}$ Lotnatigor Sihombing, Kultus dan Kultur, Sekolah Tinggi Theologia I-3, Batu, 1997

${ }^{51}$ Louis Berkhof, Teologi Sistematika: Doktrin Gereja ,Lembaga Reformed Injili Indonesia, Momentum, Surabaya, 1997

52 Reginald Fuller, The Foundations of New Testament Christology, New York: Charles Scribner's 
demikian semakin jelaslah bahwa identitas Gereja, bukan lagi sebagai pendukung "tata cara ibadat" sinagoge melainkan sebagai orang-orang yang telah percaya kepada Tuhan Yesus Kristus. Selain itu Alkitab juga memberikan begitu banyak pengajaran tentang sifat dan relasi gereja dengan Kristus, baik secara eksplisit maupun secara implisit dengan tiga aspek manifestasi pelayanan gereja yaitu didaskalos (pengajaran) marturia (kesaksian), koinonia (persekutuan) dan diakonia (pelayanan).

Perlu ditambahkan bahwa istilah ekklesia dalam Perjanjian Baru yang oleh David Watson mengali pemakaiannya dengan empat pengertian yang berbeda, yaitu:

1. Universal Church, menunjuk kepada pengertian gereja secara universal, sebagai persekutuan orang percaya (Efesus 1:22; 3:10, 21; 1 Korintus 10:32;12:28; Filipi 3:6; Kolose 1:58, dll.)

2. Particular Local Church, pengertian gereja lokal, sebagai jemaat di Kenkrea, Korintus, Laodikia, dll.

3. Actual Assembly, dalam arti sebagai jemaat di beberapa tempat, dalam persekutuan, dalam ibadat bersama (1 Korintus 11:18; 14:19, 23).

4. Small House Church, dipakai untuk menunjuk tempat ibadah atau rumah yang biasa dipakai untuk berkumpul oleh sekelompok kecil jemaat sebagai ekklesia domestis (Roma 16:5; I Korintus 16:19) 53 .

Dalam Alkitab Perjanjian Baru, Yesus Kristus menyebut para pengikut-Nya dengan sebutan "JemaatKu" (Matius 16:18) dalam pengertian bahwa gereja adalah milik Tuhan Yesus Kristus. Karena itu gereja di dalam Perjanjian Baru diartikan sebagai tubuh Kristus, dan Kristus adalah kepala gereja atau jemaat.

Pendapat beberapa teolog tentang pengertian gereja secara universal dalam Perjanjian Baru. Charles C Ryrei mengatakan: Gereja secara universal adalah semua orang percaya di Sorga dan di bumi. ${ }^{54}$ Sedangkan A. H. Strong mengatakan: Gereja secara universal adalah semua kumpulan dari orang-orang percaya, disemua masa dan abad, di bumi dan di Sorga. 55 Pernyataan-pernyataan ini hanya menyoroti gereja dari perspektif Alkitab yaitu orang-orang yang dipilih dan panggil Allah keluar dari kegelapan dosa kepada terang yang ajaib yaitu Yesus Kristus. Dalam hal ini, tidak menyoroti gereja dari gedung tempat persekutuan orang percaya dan organisasi gereja sebagai badan hukum yang menjamin legalitas gereja dalam pemerintahan manusia di dunia.

Menurut Henry Thiessen: Gereja secara universal sebagai mempelai perempuan Kristus. ${ }^{56}$ Sedangkan Tom Jacobs mengatakan: semua orang percaya adalah jemaat Allah. ${ }^{57}$ Pernyataan ke dua teolog ini berhubungan dengan gereja universal yang dapat dipahami bahwa gereja adalah persekutuan semua orang yang percaya kepada Allah dalam Yesus Kristus, yang ada pada segala waktu dan segala tempat yang digambarkan

\footnotetext{
${ }^{53}$ William Childs Robinson, "Church," dalam Baker's Dictionary of Theology, ed. Everett Harisson ,Grand Rapids: Baker Book House, 1981

${ }^{54}$ Charles C Ryei, Teologi Dasar II, (Yogjakarta: Yayasan Andi, 1992), hlm. 186.

${ }^{55}$ A.H. Strong, Systimatic Theology, (Valley Forge PA. Judson Press, 1979), hlm. 891.

${ }^{56}$ Henry Theissen, Teologi Sistimatika, (Malang: Gamdum Mas, 1992), hlm. 477.

${ }^{57}$ Tom Jacobs, Gereja Menurut Perjanjian Baru, (Yogjakarta: Kanisius, 1998), hlm. 45.
} 
sebagai mempelai perempuan yang menantikan kedatangan Yesus Kristus yang kedua kali sebagai sang mempelai laki-laki Sorga untuk menjemput gereja ke Sorga.

Menurut Charles Ryrei, Gereja lokal adalah perhimpunan tertentu, tempat bersekutu terus-menerus ${ }^{58}$. Selanjutnya A. H. Strong mengatakan: Gereja lokal adalah mereka selalu bersama secara sukarela berkenaan dengan hukum-hukum Kristus dengan tujuan mendapatkan penegakan yang sempurna dari kerajaanNya didalam diri mereka dan dunia ${ }^{59}$. Sedangkan Tom Jacobs berpendapat bahwa: Gereja lokal adalah orang-orang percaya di suatu tempat tertentu ${ }^{60}$. Jadi pengertian gereja lokal adalah persekutuan orang-orang percaya, yang dilakukan dengan senang hati dalam kasih Kristus yang terkonsentrasi di suatu tempat tertentu secara berkesinambungan.

Gereja lokal yang demikian, membutuhkan penggembalaan yang terarah pada persekutuan dengan Tuhan Yesus Kristus ke arah pertumbuhan pengetahuan firman Tuhan yang Alkitabiah yang berdampak pada pertumbuhan iman dan karakter Tuhan Yesus Kristus sebagai gambaran Tuhan Yesus Kristus di dalam pribadi setiap orang percaya.

\section{Pengertian Pertumbuhan gereja}

Pembahasaan tentang pertumbuhan gereja merupakan topik menarik yang sudah, sedang akan terus dibahas sebagai bagian dari upaya di dalam gereja Tuhan untuk menggenapi Amanat Agung Yesus Kristus di dunia ini.

Dalam pembahasan tentang pertumbuhan gereja, John Virgil mengatakan bahwa: Pengertian atau defenisi mengenai istilah pertumbuhan gereja secara teologis yakni sebagai manifestasi atau perwujudan Amanat Agung Yesus Kristus dalam (Matius 28:1920; Markus 16:15; Lukas 24:47-48; Yohanes 20:21; Kisah Para Rasul 1:8) untuk membangun gereja (bukan gedung) dalam segala jenis pertumbuhan.61 Maksudnya, pertumbuhan gereja merupakan kegerakan Allah melalui gereja-Nya untuk membawa keluar sebanyak mungkin orang yang masih berada dalam kegelapan dosa kepada terang-Nya yang ajaib yaitu Yesus Kristus. Pernyataan ini lebih berorientasi pada keselamatan jiwa-jiwa yaitu: penggenapan Amanat Agung Tuhan Yesus Kristus dalam Matius 28:18-20, dan bukan gedung gereja dan organisasi gereja. Hal ini penting, sebab dampak dari keselamatan jiwa-jiwa ialah pembanguan tempat ibadah atau gedung gereja dan pembentukan organisasi gereja untuk menata pelayanan gereja agar terencana dan sistimatis.

Essensi kegerakan pertumbuhan gereja adalah perintah Allah untuk; “ ... pergilah menjadikan semua bangsa muridKu dan ..." (Matius 28:19-20); ... "pergilah keseluruh dunia beritakan Injil ..." (Markus 16:15); “... berita tentang pertobatan dan pengampunan dosa harus disampaikan, ...” (Lukas 24:47-48); “... Sama seperti Bapa mengutus Aku, ... Aku mengutus kamu.” (Yohanes 20:21); “ ... dan kamu akan menjadi saksiKu ... sampai ke ujung bumi." (Kisah Para Rasul 1:8). Kondisi pertumbuhan gereja

\footnotetext{
${ }^{58}$ Charles C Ryei, Teologi Dasar II, hlm. 186.

${ }^{59}$ A.H. Strong, Systimatic Theology, hlm. 890.

${ }^{60}$ Tom Jacobs, Gereja Menurut Perjanjian Baru, hlm. 45

${ }^{61}$ John Virgil, Kompleksitas Pengembangan Gereja, (Jakarta: Yayasan Kasih Imanuel, 2001), hlm. 6.
} 
seperti inilah yang menyebabkan gereja dapat eksis secara dinamis. Jadi pertumbuhan gereja harus dalam segala segi/jenis atau hal yang memanifestasikan Amanat Agung Yesus Kristus.

C. Peter Wagner mendefenisikan bahwa Pertumbuhan gereja adalah segala sesuatu yang mencakup soal membawa orang-orang yang tidak memiliki hubunggan dengan Yesus Kristus ke dalam persekutuan dengan Dia dan membawa mereka menjadi anggota gereja yang bertanggung jawab ${ }^{62}$. Berhubungan dengan defenisi diatas, maka Ron Jenson dan Jim Steven, defenisikan pertumbuhan gereja sebagai berikut: Pertumbuhan gereja adalah kenaikan yang seimbang dalam kuantitas, kualitas dan kompleksitas organisasi sebuah gereja lokal.63 Defenisi ini merupakan kunci untuk memahami proses penyebab pertumbuhan gereja. Apabila ketiga komponen kenaikan dimaksud ini tidak terjadi secara seimbang, maka sebuah gereja tidak akan mempertahankan kesehatan yang baik.

Pertumbuhan gereja ialah perkembangan dan perluasan tubuh Kristus (orang Percaya), yang mencakup kuantitas, kualitas, maupun organik. ${ }^{64}$ Pertumbuhan gereja harus seimbang antara kuantitas, kualitas dan organik atau struktural organisasi, karena pertumbuhan kuantitas merupakan dampak dari pertumbuhan kualitas yang secara otomatis akan mempengaruhi pertumbuhan struktural dalam organisasi.

Mengenai essensi pertumbuhan gereja George W Peters mengatakan: Gereja juga harus bertumbuh (Efesus 4:16) sehingga anggotanya berlibat ganda dari tiap-tiap suku dan kaum dan bahasa dan bangsa (Wahyu 5:9) ${ }^{65}$. Maksudnya gereja merupakan alat Tuhan di dunia ini untuk melaksanakan rencana dan maksud yang telah ditetapkan Allah yaitu Amanat Agung Yesus Kristus umat menjangkau seluruh umat manusia menjadi umatNya.

Bruce Milne mengatakan: seharusnya gereja lebih merupakan organisme dari pada organisasi, karena gereja adalah sesuatu yang hidup dan bertumbuh dalam kualitas dan kuantitas ${ }^{66}$. Pengertian gereja sebagai organisme yang hidup dan sehat adalah gereja yang terus mengikuti kegerakan Allah sesuai pola Alkitab.

Gereja sebagai organisme yang hidup dan bertumbuh sesuai kegerakan Allah akan berpengaruh bagi dunia sesuai essensi gereja sebagai garam dan terang dunia.

Pola pertumbuhan gereja yang Alkitabiah adalah pola pelayanan dan pertumbuhan gereja mula-mula (Kisah Para Rasul 2:41-47) sesuai kegerakan Allah yang selalu berkembang sesuai perkembangan zaman.

\section{Konsep Dasar Pertumbuhan gereja}

Alkitab sebagai dasar pertumbuhan gereja yang sangat prinsip dan fundamental karena merupakan program Allah. Sebab tujuan utama Allah menciptakan dunia serta segala isinya adalah untuk kemuliaanNya melalui manusia. Namun rencana Allah

\footnotetext{
${ }^{62}$ C.Peter Wagner, Strategi Perkembangan Gereja, (Malang: Gandum Mas) hlm. 24.

${ }^{63}$ Ron Jenson dan Jim Steven, Dinamika Pertumbuhan Gereja, (Malang: Gandum Mas, 1996) hlm. 8.

${ }^{64}$ John Virgil, Kompleksitas Pengembangan Gereja, hlm. 10.

${ }^{65}$ George W. Peters, Strategi Pertumbuhan Gereja, (Malang: Gandum Mas, 2002). hlm. 25.

${ }^{66}$ Bruce Milne, Mengenali Kebenaran, (Jakarta: BPK Gunung Mulia,1996) hlm. 316.
} 
tertunda ketika manusia jatuh dalam dosa dan terpisah dari Allah. Tetapi saat itu juga, Allah menjanjikan seorang penyelamat memulihkan hubungan manusia dengan Allah (Kejadian 3:15).

Kemudian janji pemulihan ini tergenapi di dalam Yesus Kristus, untuk mencari dan menyelamatkan yang hilang (Lukas 19:10). Sebagai upaya untuk menyukseskan program tersebut Allah membangun gerejaNya dan melibatkan manusia melalui Amanat Agung yang disampaikan Yesus Kristus saat sebelum terangkat kembali ke Sorga.

Mengenai Dasar pertumbuhan gereja John Virgil mengatakan: Gerakan pertumbuhan gereja yang baik dan utuh harus berdasarkan dan menyatakan, bahwa pertumbuhan gereja itu merupakan kehendak Allah yang Maha Tinggi. ${ }^{67}$. Dari pernyataan ini dapat dipahami bahwa Allah menginginkan agar domba-dombaNya yang hilang ditemukan dan mempergandakan jumlahnya. Gereja merupakan wadah Allah untuk mengembalikan manusia kepada tujuan Allah yang semula yaitu untuk hidup bersama Allah, memuliakan Allah dan menjadi rekan sekerja Allah. Sedangkan menurut Rick Warren mengatakan bahwa: "Pertumbuhan gereja tidak dapat dihasilkan oleh manusia! Hanya Allah yang dapat membuat gereja bertumbuh."68 Pernyataan yang bertolak dari segudang pengalaman dan prestasi ini, bermula dari pemahaman yang Alkitabiah tentang gereja sebagai milik Allah maka Allah yang memberi pertumbuhan. Jadi pertumbuhan gereja sebagai organisme tubuh Yesus Kristus yang hidup akan terus bergerak secara dinamis dan inovatif sesuai kegerakan Allah dari zaman ke zaman kearah kesempurnaan Kristus harus tetap berpijak pada Alkitab.

Berhubungan dengan dasar pertumbuhan gereja, Billy Graham, mengatakan; Sebutan gereja dalam hubungannyaa dengan orang-orang Kristen dipergunakan pertama kali oleh Yesus sendiri waktu Ia berkata kepada Petrus, "Di atas batu karang ini Aku akan mendirikan jemaatKu....(Matius 16:18)"69 Jadi Yesus Kristus sendiri yang mencetuskan dan mendirikan gerejaNya diatas diriNya sebagai dasar yang teguh. Karena itu pertumbuhan gereja harus sesuai dengan konsep dasar pertumbuhan gereja yang sudah diletak Tuhan Yesus.

Pedoman pelayanan pertumbuhan berdasarkan Alkitab dapat ditinjau berdasarkan kedua perjanjian dalam Alkitab, yaitu:

a. Konsep Pertumbuhan Gereja Menurut Perjanjian Lama

Konsep pertumbuhan gereja menurut Perjanjian Lama adalah:

1. Mandat Allah kepada Adam, "Beranakcuculah dan bertambah banyak; penuhlah bumi dan .." (Kejadian 1:28).

2. Panggilan Allah kepada Abraham, ... "Pergilah dari negerimu ... ke negeri yang akan Kutunjukkan kepadamu; Aku akan membuat engkau menjadi bangsa yang besar, ..." (Kejadian 12:1-3).

Berdasarkan kedua ayat Alkitab ini, maka John Virgil mengatakan bahwa: Allah memandatkannya kepada manusia yang diawali dengan ungkapan perjanjian Lama

\footnotetext{
${ }^{67}$ John Virgil, Kompleksitas Pengembangan Gereja, hlm. 5.

${ }^{68}$ Rick Warren; The Purpose Driven Church, (Malang, Gandum Mas, 2005), hlm. 18.

${ }^{69}$ Billy Graham, Damai Dengan Allah, (Jakarta: YKBK, 1988) hlm. 233.
} 
dalam Kejadian 1, Allah menciptakan dunia serta isinya dan memberkatinya, serta memandatkannya kepada manusia untuk mengelolah dan memeliharanya ${ }^{70}$. Manusia diberikan tanggung jawab untuk berkembang dan mengembangkan dunia. Inilah berkat Allah dan panggilan fungsional kepada Adam untuk bertambah banyak dan memenuhi bumi.

Kemudian secara spesifik Allah memanggil Abraham untuk menjadi bangsa yang besar dan menjadi berkat. Panggilan Allah kepada Abraham merupakan mandat bagi pertumbuhan gereja. Jika Allah yang memandatkan pertumbuhan gereja, maka Allah bertanggung jawab atasnya.

Selanjutnya David F. Hinson mengatakan: Berita Alkitab mengenai sejarah Israel dimulai dengan panggilan Allah kepada Abraham untuk menjadi bapa dari suatu bangsa baru. ${ }^{71}$ Karena gereja bermula dari agama Yahudi yang adalah keturunan Abraham, maka dapat disimpulkan bahwa Amanat Agung dan dasar Alkitab Perjanjian Lama pertumbuhan gereja dimulai dari panggil Allah kepada Abraham. Karena itu Allah menetapkan bahwa dari keturunan Abraham semua bangsa di bumi akan diberkati. yaitu diselamatkan dari perbudakan dosa, dan nubuatan ini tergenapi didalam Tuhan Yesus Kristus (Kejadian 12:1-3; Matius 1:1-17; Galatia 3:29).

\section{Konsep Pertumbuhan Gereja Menurut Perjanjian Baru}

Konsep dasar teologis pertumbuhan gereja menurut Perjanjian Baru adalah: Yesus Kristus menginstruksikan murid-murid-Nya untuk pergi memberitakan Injil atau Amanat Agung (Matius 28:19-20; Markus 16:15; Lukas 24:47-48; Yohanes 20:21; Kisah Para Rasul 1:8), karena Yesus Kristus kehendaki melalui pemberitaan Injil adalah menyelamatkan dan menjadikan semua bangsa muridNya.

Mengenai pertumbuhan gereja merupakan Amanat Agung, maka John Virgil mengatakan bahwa; Allah menginjili Abraham dan memandatkan penginjilan kepada manusia. Hal ini terungkap jelas dalam Matius 28:19-20. Penginjilan ini dimulai di hati Allah. Oleh karena itu penginjilan bukan sekedar kabar baik, melainkan perjanjian Allah dengan manusia untuk membawa shalom. ${ }^{72}$ Allah memulai pertumbuhan gereja dengan mengadakan penginjilan kepada Abraham (Kejadian 12:1-3 dan Galatia 3:8) kemudian Allah menjadi manusia untuk menyelamatkan dan melibatkan manusia dalam proyek penyelamatan. Jadi Amanat Agung sebagai bukti Allah melibatkan manusia dalam proyek penyelamatan itu. Karena itu pertumbuhan gereja hanya akan cocok, bila melihat penduduk dunia di bawa kepada Kristus. Disinilah Allah ingin melihat hasil nyata dari pelayanan umatNya.

Amanat Agung Tuhan Yesus Kristus, dicatat dari prespektif yang berbeda-beda oleh para penulis Injil, namun dalam satu kerangka tujuan sesuai maksud Tuhan Yesus Kristus yaitu agar Injil diberitakan sampai ke ujung-ujung bumi dan semua bangsa dijadikan muridNya.

\footnotetext{
${ }^{70}$ John Virgil, Kompleksitas Pengembangan Gereja, hlm. 13.

${ }^{71}$ David F. Hinson, Sejarah Israel Pada zaman Alkitab, (Jakarta: BPK. Gunung Mulia, 1996), hlm. 30.

${ }^{72}$ John Virgil, Kompleksitas Pengembangan Gereja, hlm. 14
} 


\section{Kesimpulan}

Pertumbuhan Gereja dapat terjadi dalam dua jenis yakni: pertumbuhan kualitative dan kuantitative. Kedua jenis pertumbuhan tersebut akan diuraikan sesuai pertumbuhan gereja menurut kitab Kisah Para Rasul 2:41-47, sebagai berikut:

\section{Pertumbuhan Gereja secara Kualitatif}

Pertumbuhan kualitative berhubungan dengan kedewasaan jemaat dalam Kristus. Perhatikan jemaat mula-mula di Yerusalem yang bertumbuh secara kualitative melalui empat pilar pelayanan para murid yang kemudian dikenal dengan istilah empat pilar utama pelayanan gereja, sebagai berikut;

\section{Pertumbuhan Gereja Melalui Pengajaran Firman Tuhan}

Gereja mula-mula kuat dalam pengajaran Firman Tuhan oleh para rasul. Karena itu Charles F. Pfeiffer dan Evertt F. Harrison mengatakan: "Pengajaran rasul-rasul. Pengajaran Tuhan, bersama dengan pemberitaan tentang kehidupan, kematian dan kebangkitan Yesus serta maknanya bagi keselamatan manusia. Pengajaran ini merupakan tradisi resmi di gereja mula-mula dan kemudian dimasukkan dalam Perjanjian Baru".73 Kemudian dilaporakan bahwa "Mereka menuruti ajaran dan persekutuan para rasul, setiap hari jumlah mereka bertambah, mereka memuji Allah dan disukai semua orang." 74 Selanjutnya Bruce Milne mengatakan; "Dalam ibadah Kristen mula-mula Alkitab dibacakan didepan umum (Kolose 4:16; I Tesalonika 5:27) dan diuraikan (Kisah para rasul 2:42-43; 6:2)" ${ }^{75}$ Dari pernyataan para teolog tersebut, maka dapat disimpulkan bahwa, betapa pentingnya pengajaran Firman Tuhan bagi gereja Tuhan.

Adapun Fokus pengajaran para rasul adalah tentang kehidupan Yesus Kristus yaitu; kelahiran, kematian, kebangkitan, kenaikanNya dan pencurahan Roh Kudus sebagai penggenapan janjiNya serta maknanya bagi keselamatan manusia. Maka tiaptiap hari Tuhan menambah jumlah mereka dengan orang yang diselamatkan (2:47), karena orang-orang dengan terus-menerus, satu-persatu, menerima keselamatan dari pengajaran para rasul.

Dampak fokus pengajaran Firman Tuhan oleh para rasul adalah gereja mula-mula bertumbuh secara kualitas karena ada pelayanan khusus tentang pengajaran firman Tuhan secara fokus oleh para rasul. Supaya konsentrasi pelayanan firman Tuhan tidak terganggu, maka para rasul memilih ketujuh orang diaken untuk pelayanan kasih atau pelayanan meja (Kisah Para Rasul 6:1-4). Jadi pertumbuhan gereja secara kualitas merupakan dampak pengajaran Firman Tuhan yang Alkitab oleh para pemimpin gereja.

${ }^{73}$ Ibid. Charles F. Pfeiffer dan Evertt F. Harrison, Tafsiran Alkitab WYCLIFFE Volume 3 Perjanjian

${ }^{74}$ Tim penyusun, Tafsiran Alkitab Masa Kini 3 Matius - Wahyu, hlm.344.

${ }^{75}$ Bruce Milne, Mengenal Kebenaran, (Jakarta: BPK Gunung Mulia, 1996), hlm 307. 


\section{Pertumbuhan Gereja Melalui Pelayanan persekutuan}

Pelayanan pertumbuhan Gereja mula-mula dimulai dari pelayanan persekutuan yang di dalam bahasa Yunani dikenal dengan istilah Koinonia. Tentang permulaan jemaat mula-mula Dr. Tom Jacobs SJ, mengatakan bahwa; "Jemaat Kristen pertama berdiri di Yerusalem. Jemaat ini terdiri dari orang-orang yang sejak semula mengikut Tuhan Yesus (Kisah 1:12-26). Bersama para rasul orang-orang ini bertekun, sehati dalam doa bersama-sama menantikan janji Bapa (Kisah1:14)."76 Maksudnya gereja mula-mula dimulai oleh para rasul melalui pelayanan persekutuan yang beranggotakan murid-murid bersama seratus dua puluh (120) orang pengikut Yesus lainnya (Kisah $1: 15)$.

Menurut Charles F. Pfeiffer dan Evertt F. Harrison: "orang-orang pada masa itu menyukai persekutuan satu dengan yang lain."77 Selanjutnya “ ... gambaran masyarakat Kristen pertama, berkumpul setiap hari di rumah-rumah jemaat untuk belajar firman Tuhan, makan bersama (memecahkan roti) dan berdoa bersama. "Mereka berkumpul secara umum di tempat-tempat tertentu di kompleks Bait Allah (menurut 3:11 dan 5:12 di Serambi Salomo)". ${ }^{78}$ Persekutuan merupakan warisan dari gereja mula-mula. Adapun tujuan persekutuan ialah untuk belajar Firman Tuhan, makan bersaama dan berdoa bersama secara teratur. Kehidupan Kristen yang demikian menjadi kesaksian bagi semua orang disekitar komunitas Kristen pertama tersebut. Dengan kehidupan demikian, maka disenangi orang-orang yang menyaksikannya, sehingga “... tiap-tiap hari Tuhan menambah jumlah mereka dengan orang yang diselamatkan" (Kisah Para Rasul 2:47).

\section{Pertumbuhan Gereja Melalui Pelayanan kasih}

Selain pelayanan lewat persekutuan dan pengajaran para rasul, jemaat mulamula juga kuat dalam pelayanan kasih (Diakonia). "Persekutuan ditunjukkan dalam memecahkan roti dan berdoa dan juga dalam memiliki harta bersama (Kisah para rasul 2:45)."79 Tentang pelayanan Kasih jemaat mula-mula Charles F. Pfeiffer dan Evertt F. Harrison mengatakan: "Betapa saling mengasihinya orang-orang dalam persekutuan pertama sehingga orang percaya yang kaya menjual harta milik mereka untuk membantu memenuhi kebutuhan orang percaya yang miskin."80 Jadi pelayanan kasih jemaat mula-mula dipraktekan lewat dukungan keuangan bagi anggota jemaat yang kurang mampu dalam keuangan. Saling berbagi kesulitan diantara orang jemaat mulamula, merupakan gambaran kehidupan Kristen yang disenangi semua orang, karena mampu membangun keharmonisan sesama orang percaya sekalipun dimasa sulit

\footnotetext{
${ }^{76}$ Dr. Tom Jacobs SJ, Gereja Menurut Perjanjian Baru, (Yogyakarta: Kanasius, 1992), hlm. 83.

${ }^{77}$ Charles F. Pfeiffer dan Evertt F. Harrison, Tafsiran Alkitab WYCLIFFE Volume 3 Perjanjian Baru, (Malang: Gandum Mas, 2008), hlm. 410

${ }^{78}$ Tim penyusun, Tafsiran Alkitab Masa Kini 3 Matius - Wahyu (Jakarta: Yayasan Komunikasi Bina Kasih, 2010) hlm.344.

${ }^{79}$ Tim penyusun, Tafsiran Alkitab Masa Kini 3 Matius - Wahyu, hlm.345.

${ }^{80}$ Charles F. Pfeiffer dan Evertt F. Harrison, Tafsiran Alkitab WYCLIFFE Volume 3 Perjanjian Baru, hlm 410
} 


\section{Pertumbuhan Gereja Melalui kesaksian.}

Dampak dari kehidupan jemaat mula-mula dalam persekutuan (Koinonia), pengajaran (Didaskalia) para rasul, dan pelayanan kasih (Diakonia) adalah jemaat mula-mula hidup dalam kesaksian (Marturia). Mengenai keberanian bersaksi, Dr. H. Berkhof dan Dr. I.H. Enklaar mengatakan: "Hari kelahiran gereja ialah hari keturunan Roh Kudus pada pesta Pentakosta. Murid-murid dipenuhi Roh Kristus, sehingga mereka berani bersaksi tentang kelepasan yang dikaruniakan Tuhan kepada dunia. Dimana orang menyambut Injil dengan percaya kepada Yesus Kristus." ${ }^{81}$ Maksudnya gereja lahir dan bertumbuh karena peranan Roh Kudus dalam orang-orang percaya untuk bersaksi. Hal ini merupakan fenomena yang alkitabiah dan berkesinambungan dalam pertumbuhan gereja.

Tentang pertumbuhan gereja melalui kesaksian Merrill C. Tenney katakan: “..., tercerai-berainya para pengikut gereja ini, melahirkan pelbagai proyek misi; beberapa diantaranya diceritakan dalam bagian berikutnya tentang masa transisi (Kisah para rasul 8:4-11:8)."82 Terkadang gereja teraniaya karena diijinkan Tuhan agar gereja pergi bersaksi, membuka ladang misi yang baru. Maka Louis Berkhof berkata; “Tugas gereja bukan saja menjaga kebenaran Firman Tuhan, tetapi juga memberitakannya keseluruh dunia selain juga diberitakan dalam persekutuan umat Allah supaya orang berdosa bertobat dan orang kudus dididik dalam kebenarannya. Gereja mempunyai tugas untuk memberitakan Injil di dunia ini." ${ }^{33}$ Maksud para teolog bahwa tugas gereja di bumi adalah bersaksi agar gereja bertumbuh atau bertambah jumlah bilangan orang percaya. Jadi bagi gereja kesaksian merupakan pelaksanaan Amanat Agung Yesus Kristus yang wajib dilaksanakan tanpa kompromi oleh gereja Tuhan.

Kewajiban untuk bersaksi ini, harus dimulai dari dalam persekutuan umat Tuhan yaitu gereja itu sendiri, supaya ada pertobatan dan juga mempersiapkan generasi yang mau bersaksi untuk pertumbuhan gereja. Karena itu John Virgil, M.Th. mengatakan: "Kualitas orang Kristen mencakup kehidupan Kristus yang diperolehnya. Oleh karena itu, ketaatan dari hasil penginjilan dan kesaksian hidup orang Kristen harus dinyatakan dalam bilangan." 84

Maksudnya, pertumbuhan gereja yang sehat diawali dengan pertumbuhan kualitas atau kedewasan rohani jemaat Tuhan dengan menerapkan pengajaran Firman Tuhan yang Alkitabiah. Karena bila dicermati dengan seksama, maka Kisah Para Rasul 2:47 menunjukkan dampak pertumbuhan kualitas jemaat mula-mula lewat ketekunan para rasul mengajarkan Firman Tuhan. Jadi pertumbuhan gereja secara kualitative pasti akan berdampak bagi bertumbuh secara kuantitative.

Dengan demikian, maka gereja Tuhan harus berpegang teguh pada keempat pilar dasar pelayanan gereja yaitu Pelayanan Koinonia, Pelayanan Didaskalia, Pelayanan Diakonia, dan Pelayanan Maturia, agar gereja mengalami pertumbuhan yang sehat dan seimbang.

\footnotetext{
${ }^{81}$ Dr.H.Berkhof dan Dr.I.H.Enklaar, Sejarah Gereja (Jakarta: BPK Gunung Mulia, 2010) hlm 7.

${ }^{82}$ Merrill C. Tenney, Survei Perjanjian Baru, hlm 297.

${ }^{83}$ Louis Berkhof, Teologi Sistimatika Volume 5 Doktrin Gereja, (Surabaya: Momentum, 2010) hlm. 83.

${ }^{84}$ John Virgil, Kompleksitas Pengembangan Gereja, hlm. 22
} 


\section{Pertumbuhan Gereja secara Kuantitatif}

Pertumbuhan gereja secara kuantitative adalah pertumbuhan secara jumlah anggota jemaat. Gereja mula-mula berawal pada hari Pentakosta (Kisah Para Rasul 2:4147) dengan anggota jemaat sebanyak seratus dua puluh orang (Kisah Para Rasul 1:15). Pada hari Pentakosta sebanyak tiga ribu orang mengambil keputusan untuk mengakui Yesus adalah Kristus dan Tuhan, setelah mendengarkan khotbah rasul Petrus (Kisah Para Rasul 2:41). Selanjutnya tiap-tiap hari Tuhan menambahkan jumlah orang yang diselamatkan (Kisah Para Rasul 2:41-47). Angka pertumbuhan jemaat terus bertambah karena pengajaran Firman Tuhan, sehingga bertambah menjadi kira-kira lima ribu lakilaki orang (Kisah Para Rasul 4:4). Bahkan bilangan orang percaya semakin bertambah (Kisah Para Rasul 5:14) melalui kesaksian orang percaya, pengajaran Firman Tuhan oleh para rasul.

Tentang pertumbuhan gereja secara kuantitas John Virgil, M.Th. mengatakan: "Bilangan menunjukkan jumlah atau kuantitas adalah tanda dari kualitas."85 Jadi pertumbuhan kuantitas bermula dari pertumbuhan kualitas jemaat, sebaliknya pertumbuhan gereja secara kuantitas merupakan barometer mengetahui pertumbuhan gereja secara kualitas.

Adapun faktor-faktor pertumbuhan gereja secara kuantitave sebagai dampak pertumbuhan gereja secara kualitative adalah:

\section{Pertumbuhan Gereja Karena Pertobatan}

Pengertian pertumbuhan gereja secara kuantitative karena pertobatan adalah pertambahan jemaat karena pertobatan orang-orang berdosa. Pertumbuhan ini karena pelayanan marturia atau pemebritaan Injil, kepada orang-orang yang belum mengenal Yesus Kristus, untuk mengenal dan menerima Yesus Kristus sebagai Tuhan dan Juruselamat pribadinya dan menjadi anggota gereja (Yohanes 1:12; Roma 10:9-10). Mengenai pertobatan karena penginjilan, Rick Warren Katakan: "Agar gereja anda sangat efektif dalam penginjilan, anda harus menentukan suatu target. ${ }^{86}$ Karena harus ketahui jenis orang-orang yang tinggal di daerah pelayanan, dan putuskan kelompokkelompok yang sanggup dijangkau oleh gereja. Kemudian temukan gaya penginjilan yang penting dan tepat dengan target yang hendak dijangkau. Walaupun gereja tidak pernah menjangkau smua orang, tetapi gereja khususnya cocok untuk menjangkau beberapa jenis orang tertentu, karena itu harus mengetahui orang-orang yang hendak dijangkau agar lebih mudah pelayanan penginjilan.

Dengan kata lain bahwa dalam pelayanan penginjilan, gereja harus mempunyai target, metode dan sasaran yang tepat. Karena itu gereja harus mengetahui kebutuhan masyarakat dilingkungan gereja terlebih dahulu, agar gereja dapat menentukan gaya penginjilan yang cocok untuk menjangkau dan memenangkan sebanyak mungkin jiwa bagi Yesus Kristus. Hal ini merupakan tugas tanggung jawab dari pemimpin gereja

\footnotetext{
${ }^{85}$ Ibid, hlm. 21

${ }^{86}$ Rick Warren; The Purpose Driven Church, hlm. 163.
} 
sebagai pribadi yang menerima visi Allah, yang kemudian memperlengkapi anggota jemaat dan melibatkan seluruh komponen gereja dalam pelayanan penginjilan.

Pertumbuhan gereja karena pertobatan melalui penginjilan, merupakan pertumbuhan gereja yang sungguh sangat sehat sebab menggenapi Amanat Agung Yesus Kristus, (Matius 28:18-20; Markus 16:15-18; Lukas 24:47-48; Yohanes 20:21 dan Kisah Para Rasul 1:8). Artinya pertumbuhan yang demikian yang dimaksudkan Yesus Kristus dalam Amanat Agung-Nya kepada para murid khususnya dan semua orang percaya pada umumnya.

\section{Pertumbuhan Gereja Karena Biologis}

Pengertian pertumbuhan gereja secara biologis terjadi karena anak-anak dari keluarga-keluarga Kristen yang bertumbuh menjadi dewasa, dilayani oleh gereja, di bawa kepada Kristus dan menjadi anggota gereja yang bertanggung jawab. Kemudian berkeluarga lalu memilih untuk menjadi anggota jemaat tetap di gereja tersebut. Sebagian besar gereja-gereja diseluruh dunia bertumbuh dalam pertumbuhan secara biologis. Pertumbuhan gereja secara biologis merupakan pertumbuhan secara alami yang juga pasti terjadi pada setiap gereja Tuhan dalam pertambahan jumlah bilangan jemaat Tuhan atau pertumbuhan kuantitas.

John Virgil mengatakan: "Pertumbuhan biologis adalah pertumbuhan kuantitas anggota gereja Tuhan melalui keturunan orang percaya. Pertumbuhan jenis ini penting karena sesuai dengan mandat misi Allah." ${ }^{87}$ Jadi pertumbuhan gereja secara biologis merupakan penggenapan mandat Allah kepada manusia melalui Adam dan Abraham untuk beranak cucu (Kejadian 1:28; 12: 2 dan 17:6). Pertumbuhan gereja secara biologis juga penting, karena merupakan mandat Allah dan pasti tergenapi dalam kehidupan manusia. Namun pertumbuhan gereja secara biologis bukan pertumbuhan gereja yang sehat.

\section{Pertumbuhan Gereja Karena Perpindahan}

Pertumbuhan gereja karena perpindahan anggota gereja terjadi ketika orangorang percaya meninggalkan keanggotanya pada satu gereja dan pindah ke gereja lain dengan alasan-alasan tertentu. Misalnya karena urbanisasi yaitu perpindahan anggota gereja dari desa ke kota atau sebaliknya karena alasan pekerjaan dan alasan-alasannya.

Pertumbuhan gereja karena perpindahan anggota gereja juga terjadi karena perpindahan anggota jemaat antar denominasi gereja. Contohnya perpindahan dari denominasi gereja protestan ortodoks ke denominasi gereja protestan injil atau karismatik, dengan berbagai alasan, diantaranya karena pertumbuhan iman atau karena alasan-alasan lainnya. Pertumbuhan yang demikian pasti ada, namun bukan pertumbuhan gereja yang sehat, karena tidak ada pelipatgandaan jiwa atau Amanat Agung Yesus Kristus tidak berjalan sesuai rencana Allah.

\footnotetext{
${ }^{87}$ John Virgil, Kompleksitas Pengembangan Gereja, hlm. 27
} 


\section{Referensi}

J. Sidlow Baxter, Menggali Isi Alkitab Matius S/d Kisah Para Rasul, Jakarta: Yayasan Komunitas Bina Kasih, 1991.

Tom Jacobs SJ, Gereja Menurut Perjanjian Baru, Yogyakarta: Kanasius, 1992

Tom Jacobs, Gereja Menurut Perjanjian Baru, Yogjakarta: Kanisius, 1998

Pdt. Ola Tulluan, Ph.D. Diktat Indtroduksi Perjanjian Baru, Malang: Departemen Literatur YPPII, t.th.

Merrill C. Tenney, Survei Perjanjian Baru, Malang: Gandum Mas, 2009

Billy Graham, Roh Kudus, Bandung: Lembaga Literatur Baptis, thn. 2000

Billy Graham, Damai Dengan Allah, Jakarta: YKBK, 1988

Bruce Milne, Mengenal Kebenaran, Jakarta: BPK. Gunung Mulia, 1996.

Dr. J. Verkuyl, Aku Percaya, Jakarta: BPK. Gunung Mulia, 1995

Dr. R. Sodarmo, Iktisar dogmatika, Jakarta: BPK Gunung Mulia, 2002

Paulus Daun, Pneumatologi, Manado: Yayasan Daun Family, 2004

Ichwei G. Indra, Teologi Sistimatika, Bandung: Yayasan Baptis Indonesia, 1999

Ds. H. v. d. Brink, Tafsiran Alkitab Kisah Para Rasul, Jakarta, BPK Gunung Mulia, cet. Ke-5, 2000

Gerhard A. Krodel, Augsburg Comenntary on The New Testament Acts, Minneapolis, Minnesota, 1986

F. F. Bruce, The Acts of the Apostle : The Greek Test with Introdution and Commentary, 1952

I. L. Nomensenn, "Benih Yang Bertumbuh"; Pematang siantar, 1984

W. Stanley Heath, Penginjilan dan Pelayanan Pribadi (Surabaya, Penerbit Yakin ttn.

Ir. Timotius Surbekti, Gereja dalam Pendakian Puncak Sejarah Dunia, Yogyakarta, Penerbit Yayasan Andi, cet. Ke-1, 1987.

Lotnatigor Sihombing, Kultus dan Kultur, Batu: Sekolah Tinggi Theologia I-3, 1997

Christ Marantika, Kepercayaan dan Kehidupan Kristen, Jakarta: BPK. Gunung Mulia, 1984.

Suhento Liauw, Doktrin Gereja Alkitabiah, Jakarta: Graphe, 1996

J. L. Ch. Abineno, Garis-garis Besar Hukum Gereja, Jakarta: BPK. Gunung Mulia, 1994.

Ron Jenson \& Jim Stevens, Dinamika Pertumbuhan Gereja, Malang : Gandum Mas, T. Thn.

Edmund P.Clowney, The Church Leicester: Inter Varsity Press, 1995

William Childs Robinson, "Church," dalam Baker's Dictionary of Theology, ed. Everett Harisson Grand Rapids: Baker Book House, 1981

Jusuf B. S., Kemah Suci, Surabaya, n.p. 1994

I. Oward Marshall, The Tyndale New Testament Commentary, The Acts of the Apostles, Michigan: Williams B. Eerdmans Publishing Company, 1980.

Reginald Fuller, The Foundations of New Testament Christology , New York: Charles Scribner's Sons, 1965

Charles C Ryei, Teologi Dasar II, Yogjakarta: Yayasan Andi, 1992

A. H. Strong, Systimatic Theology, Valley Forge PA. Judson Press, 1979

Henry Theissen, Teologi Sistimatika, Malang: Gamdum Mas, 1992 
John Virgil, Kompleksitas Pengembangan Gereja, Jakarta: Yayasan Kasih Imanuel, 2001 Ron Jenson dan Jim Steven, Dinamika Pertumbuhan Gereja, Malang: Gandum Mas, 1996. George W. Peters, Strategi Pertumbuhan Gereja, Malang: Gandum Mas, 2002.

Rick Warren; The Purpose Driven Church, Malang, Gandum Mas, 2005

David F. Hinson, Sejarah Israel Pada zaman Alkitab, Jakarta: BPK. Gunung Mulia, 1996.

Bruce Milne, Mengenal Kebenaran, Jakarta: BPK Gunung Mulia, 1996.

Charles F. Pfeiffer dan Evertt F. Harrison, Tafsiran Alkitab WYCLIFFE Volume 3 Perjanjian Baru, Malang: Gandum Mas, 2008

Dr. H. Berkhof dan Dr. I. H. Enklaar, Sejarah Gereja Jakarta: BPK Gunung Mulia, 2010.

Louis Berkhof, Teologi Sistematika: Doktrin Gereja , Lembaga Reformed Injili Indonesia, Momentum, Surabaya, 1997

Louis Berkhof, Teologi Sistimatika Volume 5, Doktrin Gereja, Surabaya: Momentum, 2010.

Tim penyusun, Tafsiran Alkitab Masa Kini 3 Matius - Wahyu, Jakarta: Yayasan Komunikasi Bina Kasih, 2010.

Tim Penyusun Ensiklopedia Alkitab Masa Kini Jilid I, Jakarta: Yayasan Komunikasi Bina Kasih, 2002

Tim Penyusun, Ensiklopedi Alkitab Masa Kini jilid I, Jakarta: OMF, 1994

Tim Penyusun Ensiklopedia Alkitan Masa Kini jilid II, Jakarta: Yayasan komunikasi Bina kasih, 2002 